\title{
Theoretical study of the kinetics of reactions of the monohalogenated methanes with atomic chlorine
}

\author{
Katarzyna Brudnik • Maria Twarda • \\ Dariusz Sarzyński • Jerzy T. Jodkowski
}

Received: 9 September 2012 /Accepted: 22 November 2012 /Published online: 14 December 2012

(C) The Author(s) 2012. This article is published with open access at Springerlink.com

\begin{abstract}
Ab}$ initio calculations at the $\mathrm{G} 2$ level were used in a theoretical description of the kinetics and mechanism of the hydrogen abstraction reactions from fluoro-, chloro- and bromomethane by chlorine atoms. The profiles of the potential energy surfaces show that mechanism of the reactions under investigation is complex and consists of two - in the case of $\mathrm{CH}_{3} \mathrm{~F}+\mathrm{Cl}$ and of three elementary steps for $\mathrm{CH}_{3} \mathrm{Cl}+\mathrm{Cl}$ and $\mathrm{CH}_{3} \mathrm{Br}+\mathrm{Cl}$. The heights of the energy barrier related to the $\mathrm{H}$-abstraction are of $8-10 \mathrm{~kJ} \mathrm{~mol}^{-1}$, the lowest value corresponds to $\mathrm{CH}_{3} \mathrm{Cl}+\mathrm{Cl}$ and the highest one to $\mathrm{CH}_{3} \mathrm{~F}+\mathrm{Cl}$. The rate constants were calculated using the theoretical method based on the RRKM theory and the simplified version of the statistical adiabatic channel model. The kinetic equations derived in this study
\end{abstract}

$$
\begin{aligned}
& k\left(\mathrm{CH}_{3} \mathrm{~F}+\mathrm{Cl}\right)=6.75 \times 10^{-12} \times(\mathrm{T} / 300)^{2.12} \\
& \times \exp (-900 / \mathrm{T}) \quad \mathrm{cm}^{3} \text { molecule }^{-1} \mathrm{~s}^{-1} \\
& k\left(\mathrm{CH}_{3} \mathrm{Cl}+\mathrm{Cl}\right)=6.97 \times 10^{-12} \times(\mathrm{T} / 300)^{1.73} \\
& \times \exp (-795 / \mathrm{T}) \quad \mathrm{cm}^{3} \text { molecule }^{-1} \mathrm{~s}^{-1} \\
& k\left(\mathrm{CH}_{3} \mathrm{Br}+\mathrm{Cl}\right)=6.26 \times 10^{-12} \times(\mathrm{T} / 300)^{1.82} \\
& \times \exp (-795 / \mathrm{T}) \quad \mathrm{cm}^{3} \text { molecule } \mathrm{l}^{-1} \mathrm{~s}^{-1}
\end{aligned}
$$

and

$$
\begin{aligned}
& k\left(\mathrm{CH}_{2} \mathrm{~F}+\mathrm{HCl}\right)=2.88 \times 10^{-13} \times(\mathrm{T} / 300)^{2.02} \\
& \times \exp (-1255 / \mathrm{T}) \quad \mathrm{cm}^{3} \text { molecule }^{-1} \mathrm{~s}^{-1} \\
& k\left(\mathrm{CH}_{2} \mathrm{Cl}+\mathrm{HCl}\right)=2.42 \times 10^{-13} \times(\mathrm{T} / 300)^{1.57} \\
& \times \exp (-2100 / \mathrm{T}) \quad \mathrm{cm}^{3} \text { molecule }{ }^{-1} \mathrm{~s}^{-1} \\
& k\left(\mathrm{CH}_{2} \mathrm{Br}+\mathrm{HCl}\right)=2.21 \times 10^{-13} \times(\mathrm{T} / 300)^{1.69} \\
& \times \exp (-1485 / \mathrm{T}) \quad \mathrm{cm}^{3} \text { molecule }{ }^{-1} \mathrm{~s}^{-1}
\end{aligned}
$$

K. Brudnik $\cdot$ M. Twarda $\cdot$ D. Sarzyński $\cdot$ J. T. Jodkowski $(\bowtie)$

Department of Physical Chemistry,

Wroclaw Medical University, pl. Nankiera 1,

50-140 Wroclaw, Poland

e-mail: jerzy.jodkowski@am.wroc.pl allow a description of the kinetics of the reactions under investigation in the temperature range of $200-3000 \mathrm{~K}$. The kinetics of reactions of the entirely deuterated reactants were also included in the kinetic analysis. Results of ab initio calculations show that D-abstraction process is related with the energy barrier of $5 \mathrm{~kJ}$ $\mathrm{mol}^{-1}$ higher than the $\mathrm{H}$-abstraction from the corresponding non-deuterated reactant molecule. The derived analytical equations for the reactions, $\mathrm{CD}_{3} \mathrm{X}+\mathrm{Cl}, \mathrm{CH}_{2} \mathrm{X}+\mathrm{HCl}$ and $\mathrm{CD}_{2} \mathrm{X}+\mathrm{DCl}$ $(\mathrm{X}=\mathrm{F}, \mathrm{Cl}$ and $\mathrm{Br}$ ) are a substantial supplement of the kinetic data necessary for the description and modeling of the processes of importance in the atmospheric chemistry.

Keywords Chemical kinetics · Gas-phase reactions . Halomethanes $\cdot$ Hydrogen abstraction $\cdot$ Kinetic isotope effect

\section{Introduction}

Chlorine atoms are important stratospheric species taking an active part in ozone destruction cycles [1,2]. The main sources of the atmospheric chlorine atoms are the photochemically labile chlorine compounds such as $\mathrm{Cl}_{2}$ and $\mathrm{ClNO}_{2}$ produced in some aqueous-phase reactions in the airborne seawater droplets. The gas-phase reactions of chlorine atoms with the hydrogen-containing atmospheric halocarbons lead to the facile generation of the corresponding free radicals via hydrogen atom abstraction $[1,3]$.

Monofluoromethane is the simplest of hydrofluorocarbons (HFCs), which are man-made organics predominantly used as safe replacements for ozone-depleting substances [1]. HFCs are chemically low reactive and have an ozone depleting potential of zero as they contain no chlorine. HFCs have long lifetimes in the atmosphere, and are only slowly removed by solar photolysis [4-6]. The main impact of HFCs on the environment is related with global warming. 
Chloromethane $\left(\mathrm{CH}_{3} \mathrm{Cl}\right)$ is the most abundant halocarbon in the atmosphere with an atmospheric lifetime of 17 months [7-9]. Major natural sources of $\mathrm{CH}_{3} \mathrm{Cl}$ are biomass burning, oceanic emissions and vegetative emissions. The products of the atmospheric destruction of $\mathrm{CH}_{3} \mathrm{Cl}$ may be involved in various catalytic atmospheric reaction cycles responsible for the depletion of the ozone layer [1]. The reaction with hydroxyl radicals is considered as the dominant sink for atmospheric $\mathrm{CH}_{3} \mathrm{Cl}$.

The most important carrier of bromine to the stratosphere is bromomethane $\left(\mathrm{CH}_{3} \mathrm{Br}\right)$ which is produced by both anthropogenic and natural processes. $\mathrm{CH}_{3} \mathrm{Br}$ is a very efficient catalyst for ozone destruction. The atmospheric lifetime of $\mathrm{CH}_{3} \mathrm{Br}$ is estimated to be approximately two years [10]. The fate of atmospheric methyl bromide is primarily determined by degradation processes in the troposphere, especially by its reaction with $\mathrm{OH}$ radicals $[1,11]$.

The hydrogen abstraction reactions of chlorine atoms with halomethanes, $\mathrm{CH}_{3} \mathrm{X}$ (where $\mathrm{X}=\mathrm{F}, \mathrm{Cl}, \mathrm{Br}$ ) have been the subjects of many kinetic studies [12-14]. The primary tropospheric sink for halogenated methanes including these three of interest in this study $\left(\mathrm{CH}_{3} \mathrm{~F}, \mathrm{CH}_{3} \mathrm{Cl}\right.$ and $\left.\mathrm{CH}_{3} \mathrm{Br}\right)$ is their reaction with $\mathrm{OH}$ radicals. The recent investigations suggest that concentrations of chlorine atoms in the marine boundary layer may be as much as one-tenth as high as the hydroxyl radical levels [1]. Since reactions of $\mathrm{Cl}$ atoms with many organics proceed considerably faster than the corresponding $\mathrm{OH}$ reactions [12-14], it is possible that reactions with atomic chlorine could be a non-negligible sink for many hydrogencontaining atmospheric halomethanes.

In this study we present a theoretical analysis of the mechanism and kinetics of the reactions of monosubstituted halogenated methanes $\mathrm{CH}_{3} \mathrm{X}$ with atomic chlorine:

$\mathrm{CH}_{3} \mathrm{X}+\mathrm{Cl} \rightarrow \mathrm{CH}_{2} \mathrm{X}+\mathrm{HCl}$,

where $\mathrm{X}=\mathrm{F}, \mathrm{Cl}$ and $\mathrm{Br}$. One expects that the mechanism of the reaction (1) is complex and $\mathrm{H}$-abstraction proceeds through the formation of intermediate complexes. The possible competitive reaction channels related with the abstraction of halogen $\mathrm{X}$ from the $\mathrm{CH}_{3} \mathrm{X}$ molecule, and the formation of $\mathrm{XCl}$ products are probably related with high activation energies and proceed very slowly. Any trace of $\mathrm{XCl}$ products was not found in the experimental studies, which was the grounds to omit the halogen abstraction in the mechanism of the reactions $\mathrm{CH}_{3} \mathrm{X}+\mathrm{Cl}$.

Our theoretical analysis of the reaction systems concerns ab initio calculations using molecular orbital theory in order to locate and characterize the characteristic points of the potential energy surface. The main attention of our study is focused on the possible influence of the formed molecular complexes on the reaction mechanism. The theoretical method used for the description of the reaction kinetics enables the rate constant calculations for a bimolecular reaction proceeding through the formation of intermediate complexes. Results of these calculations provide structural and energetic information on the reaction pathways, which enable us to evaluate the rate constants and their temperature dependence using computational methods of reaction rate theory. The calculated properties of the molecular structures taking part in the reaction mechanism should be useful for a better understanding and correct interpretation of experimental findings.

The kinetics of the reactions $\mathrm{CH}_{3} \mathrm{~F} / \mathrm{CH}_{3} \mathrm{Cl} / \mathrm{CH}_{3} \mathrm{Br}+\mathrm{Cl}$ has been the subject of many experimental [15-38] and theoretical $[20,39-44]$ studies. The available experimental kinetic data show, however, substantial scattering in the values of the rate constants. The most credible and preferable for the kinetic analysis are then the results of measurements obtained by the same research group and using the same experimental method. Kinetics of the reactions $\mathrm{CH}_{3} \mathrm{~F}+\mathrm{Cl}, \mathrm{CH}_{3} \mathrm{Cl}+\mathrm{Cl}$ and $\mathrm{CH}_{3} \mathrm{Br}+\mathrm{Cl}$ was recently studied experimentally in our laboratory using the same experimental technique, the same reference reaction and performed in the same temperature range $[22,32,38]$. Besides that, the reactions of entirely deuterated reactants

$\mathrm{CD}_{3} \mathrm{X}+\mathrm{Cl} \rightarrow \mathrm{CD}_{2} \mathrm{X}+\mathrm{DCl}$,

were simultaneously studied under the same experimental conditions. The obtained results are then valuable reference data for the theoretical comparative kinetic analysis.

\section{Computational details}

The halogenated alkanes were studied theoretically using quantum mechanical ab initio methods at various levels of theory. Results of these calculations performed for a wide class of organic compounds show that the G2 method [45] reproduces well the structural parameters and molecular properties of a wide group of organic compounds. The reliable values of the thermochemical properties and vibrational frequencies have been obtained using G2 methodology for perhalogenated methanols, methyl hypohalites, halogenated alkyl and alkoxy radicals [46-56]. The G2 method was also successfully used in the theoretical description of the kinetics and mechanism of the hydrogen abstraction from methanol by halogen atoms [57-59]. Therefore, we decided to use this level of theory in our investigations.

All quantum mechanical ab initio calculations were carried out using the Gaussian 09 program [60] package. The geometries of all stationary point structures of the potential energy surface were fully optimized at both the SCF and MP2 levels with the 6-31G(d) basis set. Relative total energies were examined using G2 methodology [45]. This 
approach requires some additional calculations at the MP4/ 6-311G(d,p), MP4/6-311+G(d,p), MP4/6-311G(2df,p), MP2/6-311+G(3df,2p), and QCISD(T)/6-311G(d,p) levels using the MP2/6-31G(d) optimized geometry as a reference to obtain improved energy values.

The rate constants of the reactions studied were analyzed in terms of conventional transition-state theory (TST) [61, 62]. The thermochemical formulation of TST leads to the rate constant, $\mathrm{k}_{\mathrm{TST}}$, given by

$k_{\mathrm{TST}}=\sigma \frac{\mathrm{k}_{\mathrm{B}} \mathrm{T}}{\mathrm{h}} \exp \left(\frac{\Delta S^{\neq}}{R}\right) \exp \left(-\frac{\Delta H^{\neq}}{R T}\right)$,

where $\sigma$ denotes a symmetry factor related to reaction path degeneracy, $\mathrm{k}_{\mathrm{B}}$ and $h$ are the Boltzmann and Planck constants, respectively, $\Delta \mathrm{S}^{\neq}$is the activation entropy, and $\Delta \mathrm{H}^{\neq}$ the activation enthalpy for the reaction under investigation. The vibrational and rotational contributions to the thermodynamic functions were derived by the classical harmonicoscillator rigid-rotor approximation (no free or internal rotation was considered).

\section{Results and discussion}

The molecular arrangements and definitions of the structural parameters of the $\mathrm{CH}_{3} \mathrm{X}$ and $\mathrm{CH}_{2} \mathrm{X}(\mathrm{X}=\mathrm{F}, \mathrm{Cl}$, and $\mathrm{Br})$ structures are shown in Fig. 1. The geometries of all molecular structures taking part in the reactions under investigation were fully and independently optimized using analytical gradients at the SCF and MP2 levels with the 6-31G(d) basis set. At each level of theory the potential energy surface was explored independently for the possible existence of transition states and intermediate complexes. The results of calculations including the optimized geometrical parameters at the MP2/6$31 \mathrm{G}(\mathrm{d})$ level, the harmonic vibrational frequencies, the rotational constants and the total $\mathrm{G} 2(0 \mathrm{~K})$ energies for the reactants $\mathrm{CH}_{3} \mathrm{X}$, products $\mathrm{CH}_{2} \mathrm{X}$, molecular complexes $\mathrm{CH}_{3} \mathrm{X} \ldots$ $\mathrm{Cl}$ (denoted by $\mathrm{MC} 1 \mathrm{X}$ ) and $\mathrm{CH}_{2} \mathrm{X} \ldots \mathrm{HCl}(\mathrm{MC} 2 \mathrm{X})$ as well as transition states $\mathrm{CH}_{2} \mathrm{X} \ldots \mathrm{H}$... Cl (TS1X) are given in Tables 1 and 2. The structural parameters of the hydrogen halides, HX were published elsewhere [57-59].

\section{Optimized molecular structures}

The most stable structures of monohalogenated methanes $\mathrm{CH}_{3} \mathrm{X}$ appears to have molecular symmetry of the $\mathrm{C}_{3 \mathrm{v}}$ point group. Except for the $\mathrm{C}-\mathrm{X}$ bond lengths, the structural parameters of $\mathrm{CH}_{3} \mathrm{~F}, \mathrm{CH}_{3} \mathrm{Cl}$ and $\mathrm{CH}_{3} \mathrm{Br}$ obtained in the geometry optimization performed at the MP2(full)/6-31G(d) level are very close one to another. The halogenated methyl radicals $\mathrm{CH}_{2} \mathrm{~F}, \mathrm{CH}_{2} \mathrm{Cl}$ and $\mathrm{CH}_{2} \mathrm{Br}$ are the molecular structures with the $\mathrm{C}_{\mathrm{s}}$ symmetry. Either $\mathrm{C}-\mathrm{X}$ or $\mathrm{C}-\mathrm{H}$ bonds in these radicals are considerably shorter than their counterparts in molecules of the parent halogenated methanes. In contrast to that the values of angular parameters in $\mathrm{CH}_{2} \mathrm{X}$ radicals, $\mathrm{X}-\mathrm{C}-\mathrm{H}$ and $\mathrm{H}-\mathrm{C}-\mathrm{H}$ are distinctly greater than those in the corresponding reactants.

Except for fluoromethane, the attack of chlorine atom on molecule of halomethane leads to formation of the prereaction adducts, $\mathrm{CH}_{3} \mathrm{Cl} \ldots \mathrm{Cl}$ (denoted by $\mathrm{MClCl}$ ) and $\mathrm{CH}_{3} \mathrm{Br}$...Cl. (MC1Br). These intermediate complexes possess the $\mathrm{C}_{\mathrm{s}}$ symmetry, because the attacking chlorine atom is moving across the symmetry plane of the halomethane. The pre-reaction adducts $\mathrm{MC1X}$ are loose molecular structures with long contact distances between the attacking chlorine and $\mathrm{CH}_{3} \mathrm{X}$. The geometrical parameters of these molecular complexes retain the values which appear in the isolated reactants, $\mathrm{CH}_{3} \mathrm{Cl}$ and $\mathrm{CH}_{3} \mathrm{Br}$.

The transition states $\left(\mathrm{CH}_{2} \mathrm{X} \ldots \mathrm{H} . . \mathrm{Cl}\right)^{\neq}$, denoted by TS1X, describe the hydrogen abstraction from halomethane $\mathrm{CH}_{3} \mathrm{X}$ by $\mathrm{Cl}$ atom. Of all these saddle points, TS1X have $\mathrm{C}_{\mathrm{s}}$ symmetry, with the $\mathrm{C}-\mathrm{H}_{1}$ and $\mathrm{H}_{1}-\mathrm{Cl}$ bond located in the symmetry plane $\mathrm{XCH}_{1} \mathrm{Cl}$. The transition states, TS1X are reactant-like structures, and the attack of chlorine atom at TS1X structure is nearly collinear. The calculated lengths of the breaking bond $\mathrm{C}-\mathrm{H}_{1}$ are of $1.40 \AA$ (TS1F, TS1Br) and $1.38 \AA$ (TS1Cl), which corresponds to a relative elongation of $30 \%$ with respect to the $\mathrm{C}-\mathrm{H}$ in isolated reactants. On the other hand, the formed $\mathrm{H}_{1}-\mathrm{Cl}$ bonds of $1.45-1.46 \AA$ are about $15 \%$ longer than in $\mathrm{HCl}$ molecule. Values of the other structural parameters of the transition states TS1X are close to their counterparts in the reactants, $\mathrm{CH}_{3} \mathrm{X}$.

The post-reaction adducts, $\mathrm{CH}_{2} \mathrm{X}$... $\mathrm{HCl}$ designated by $\mathrm{MC} 2 \mathrm{X}$ are intermediates which distinctly consist of two subunits, radical $\mathrm{CH}_{2} \mathrm{X}$ and molecule of hydrogen chloride, $\mathrm{HCl}$ bonded in a molecular complex. The geometrical parameters of these subunits are close to those of the isolated molecules. The contact distances $\mathrm{C} \ldots \mathrm{H}_{1}$, are over twice as long as those in isolated reactants, $\mathrm{CH}_{3} \mathrm{X}$. All $\mathrm{MC} 2 \mathrm{X}$ complexes retain symmetry of the $\mathrm{C}_{\mathrm{s}}$ point group.

\section{Reaction energetics}

It is well known that using the G2 method leads to a realistic estimate of the total energy of a wide group of molecular structures. The accuracy of these estimations based on the G2-energies is usually considered to be better than $6 \mathrm{~kJ}$ $\mathrm{mol}^{-1}$, as was established for a set of about 150 compounds $[45,63,64]$. The enthalpy of formation, $\Delta H_{f, 298}^{0}$, can be directly evaluated as the $\mathrm{G} 2$ enthalpy at room temperature for the reaction in which the relevant molecule is formed from the gas-phase elements, such as $\mathrm{C}_{(\mathrm{g})}, \mathrm{H}_{2(\mathrm{~g})}, \mathrm{F}_{2(\mathrm{~g})}, \mathrm{Cl}_{2(\mathrm{~g})}$, and $\mathrm{Br}_{2(\mathrm{~g})}$, and by using the well-established values of enthalpy of formation at $298 \mathrm{~K}$ of gaseous carbon atom $\mathrm{C}_{(\mathrm{g})}$ and molecule of $\mathrm{Br}_{2(\mathrm{~g})}$ of $715.0 \mathrm{~kJ} \mathrm{~mol}^{-1}$ and $30.9 \mathrm{~kJ}$ $\mathrm{mol}^{-1}[12,14]$, respectively. 
Fig. 1 Definition of the geometrical parameters of the molecular structures taking part in the mechanism of the reactions $\mathrm{CH}_{3} \mathrm{X}+\mathrm{Cl}$, where $\mathrm{X}=\mathrm{F}, \mathrm{Cl}$ and $\mathrm{Br}$
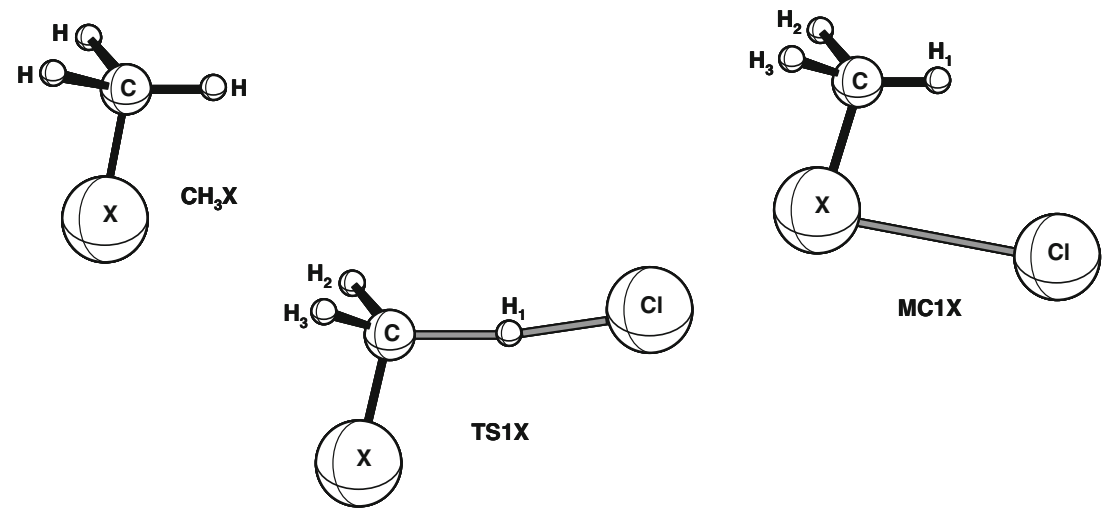

$\operatorname{MC1X}$

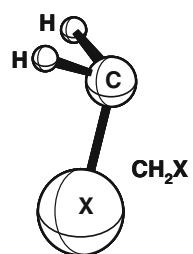

The calculated values, given in Table 3, of the enthalpy of formation $\Delta H_{f, 298}^{0}$ for reactants and products of the reactions under investigation are in very good agreement with those found experimentally $[12,14]$. The greatest divergence between theoretical and experimental estimates of $\Delta H_{f, 298}^{0}$ occurred for the bromine compounds, $\mathrm{CH}_{3} \mathrm{Br}$ and $\mathrm{CH}_{2} \mathrm{Br}$ does not exceed $6 \mathrm{~kJ} \mathrm{~mol}^{-1}$. The reaction enthalpy $\Delta H_{r, 298}^{0}$ calculated for reaction $\mathrm{CH}_{3} \mathrm{Br}+\mathrm{Cl} \leftrightarrow \mathrm{CH}_{2} \mathrm{Br}+\mathrm{HCl}$ of -6.0 $\mathrm{kJ} \mathrm{mol}^{-1}$ at room temperature is in excellent agreement with experimental one of $-6.5 \pm 5.5 \mathrm{~kJ} \mathrm{~mol}^{-1}$ [12]. The theoretical value of $\Delta H_{r, 298}^{0}$ of $-11.1 \mathrm{~kJ} \mathrm{~mol}^{-1}$ for $\mathrm{CH}_{3} \mathrm{Cl}+\mathrm{Cl} \leftrightarrow$ $\mathrm{CH}_{2} \mathrm{Cl}+\mathrm{HCl}$ is also very close to that of $-14.4 \pm 3.7 \mathrm{~kJ}$ $\mathrm{mol}^{-1}$ derived from the experimentally estimated values of $\Delta H_{f, 298}^{0}$ of the reaction reagents. The theoretical description of the reaction thermochemistry seems to be the worst for $\mathrm{CH}_{3} \mathrm{~F}+\mathrm{Cl} \leftrightarrow \mathrm{CH}_{2} \mathrm{~F}+\mathrm{HCl}$. The calculated heat of reaction of $-3.1 \mathrm{~kJ} \mathrm{~mol}^{-1}$ at $298 \mathrm{~K}$ is distinctly higher than the experimental values of $\Delta H_{r .298}^{0}$ of $-12.0 \mathrm{~kJ}$ mol [12] and $-7.6 \mathrm{~kJ}$ mol [12]. However, one should take into account that the experimental values of $\Delta H_{f, 298}^{0}$ of $\mathrm{CH}_{3} \mathrm{~F}$ and $\mathrm{CH}_{2} \mathrm{~F}$ were estimated with low precision, which may result in a final error of the reaction enthalpy of $16 \mathrm{~kJ} \mathrm{~mol}^{-1}$ or even more. Therefore, the theoretical description of the thermochemistry of the reactions under investigation based on the G2-energies should be considered as reliable.

Reaction mechanism

The hydrogen abstraction from $\mathrm{CH}_{3} \mathrm{~F}$ by $\mathrm{Cl}$ proceeds in accordance with the two-step reaction mechanism
$\mathrm{CH}_{3} \mathrm{~F}+\mathrm{Cl} \leftrightarrows \mathrm{CH}_{2} \mathrm{~F} \ldots \mathrm{HCl} \rightarrow \mathrm{CH}_{2} \mathrm{~F}+\mathrm{HCl}$

The intermediate complex, $\mathrm{MC} 2 \mathrm{~F}$ formed in the first elementary step dissociates into the final reaction products, radical $\mathrm{CH}_{2} \mathrm{~F}$ and $\mathrm{HCl}$. Profile of the potential energy surface for the $\mathrm{CH}_{3} \mathrm{~F}+\mathrm{Cl}$ reaction system is shown in Fig. 2a. The $\mathrm{H}$-abstraction reaction $\mathrm{CH}_{3} \mathrm{~F}+\mathrm{Cl}$ is a weakly exothermic process. The calculated reaction enthalpy is of $-5.9 \mathrm{~kJ}$ $\mathrm{mol}^{-1}$ at $0 \mathrm{~K}$. The post-reaction adduct, $\mathrm{CH}_{2} \mathrm{~F} \ldots \mathrm{HCl}$ (MC2F) is the lowest energy molecular structure formed during the reaction. The potential energy of $\mathrm{MC} 2 \mathrm{~F}$ at $0 \mathrm{~K}$ calculated at the $\mathrm{G} 2$ level is by $9.8 \mathrm{~kJ} \mathrm{~mol}^{-1}$ lower than the reactants' energy. The thermal stability of $\mathrm{MC} 2 \mathrm{~F}$ with respect to the reaction products, $\mathrm{CH}_{2} \mathrm{~F}+\mathrm{HCl}$ is estimated of $4.8 \mathrm{~kJ} \mathrm{~mol}^{-1}$ at $0 \mathrm{~K}$. The first elementary step is related to an energy barrier determined by the energy of the transition state, $\mathrm{CH}_{2} \mathrm{~F} \ldots \mathrm{H} \ldots \mathrm{Cl}$ (TS1F). The height of the energy barrier is relatively small of $9.9 \mathrm{~kJ} \mathrm{~mol}^{-1}$, which indicates that the decay of the reactants should be a fast process, with the rate constant of $10^{-13} \mathrm{~cm}^{3}$ molecule $\mathrm{s}^{-1} \mathrm{~s}^{-1}$ at room temperature.

In the case of the reactions $\mathrm{CH}_{3} \mathrm{Cl} / \mathrm{CH}_{3} \mathrm{Br}+\mathrm{Cl}$, the $\mathrm{H}$ abstraction process requires three elementary steps:

$\mathrm{CH}_{3} \mathrm{X}+\mathrm{Cl} \leftrightarrows \mathrm{CH}_{3} \mathrm{X} \ldots \mathrm{Cl} \leftrightarrows \mathrm{CH}_{2} \mathrm{X} \ldots \mathrm{HCl} \rightarrow \mathrm{CH}_{2} \mathrm{X}+\mathrm{HCl}$

where $\mathrm{X}=\mathrm{Cl}, \mathrm{Br}$. The hydrogen abstraction from $\mathrm{CH}_{3} \mathrm{Cl}$ and $\mathrm{CH}_{3} \mathrm{Br}$ by chlorine atom is more exothermic compared with the reaction of $\mathrm{CH}_{3} \mathrm{~F}+\mathrm{Cl}$. The profiles of the potential energy surface for these reaction systems are also shown in Fig. 2a. The first and third elementary processes are 
Table 1 Molecular properties of the reactants and products of the reactions under investigation calculated at the G2 level ${ }^{\text {a) }}$

\begin{tabular}{|c|c|c|c|c|c|c|c|c|c|}
\hline & $\mathrm{CH}_{3} \mathrm{~F}\left(\mathrm{C}_{3 \mathrm{v}}\right)$ & & & $\mathrm{CH}_{3} \mathrm{Cl}\left(\mathrm{C}_{3 \mathrm{v}}\right)$ & & & $\mathrm{CH}_{3} \mathrm{Br}\left(\mathrm{C}_{3 \mathrm{v}}\right)$ & & \\
\hline $\mathrm{C}-\mathrm{X}$ & 1.390 & & & 1.777 & & & 1.947 & & \\
\hline $\mathrm{C}-\mathrm{H}$ & 1.092 & & & 1.088 & & & 1.086 & & \\
\hline $\mathrm{H}-\mathrm{C}-\mathrm{X}$ & 109.14 & & & 108.91 & & & 107.85 & & \\
\hline $\mathrm{H}-\mathrm{C}-\mathrm{H}$ & 109.81 & & & 110.03 & & & 111.04 & & \\
\hline A & 157.134 & & & 157.847 & & & 156.354 & & \\
\hline B & 25.454 & & & 13.375 & & & 9.519 & & \\
\hline $\mathrm{C}$ & 25.454 & & & 13.375 & & & 9.519 & & \\
\hline$v_{1}$ & 1059 & 1036 & (1049) & 699 & 747 & $(732)$ & 570 & 591 & $(611)$ \\
\hline$v_{2}$ & 1171 & 1147 & (1182) & 1016 & 1031 & (1017) & 945 & 939 & $(955)$ \\
\hline$v_{3}$ & 1171 & 1147 & (1182) & 1016 & 1031 & (1017) & 945 & 939 & $(955)$ \\
\hline$v_{4}$ & 1475 & 1457 & (1464) & 1373 & 1395 & (1355) & 1323 & 1309 & $(1306)$ \\
\hline$v_{5}$ & 1476 & 1465 & (1467) & 1454 & 1469 & $(1452)$ & 1451 & 1442 & $(1443)$ \\
\hline$v_{6}$ & 1476 & 1465 & (1467) & 1454 & 1469 & $(1452)$ & 1451 & 1442 & $(1443)$ \\
\hline$v_{7}$ & 2887 & 2913 & (2930) & 2917 & 2997 & (2937) & 2930 & 2958 & (2935) \\
\hline$v_{8}$ & 2958 & 3006 & (3006) & 3010 & 3103 & (3039) & 3032 & 3074 & (3056) \\
\hline$v_{9}$ & 2958 & 3006 & (3006) & 3010 & 3104 & (3039) & 3032 & 3074 & (3056) \\
\hline \multirow[t]{2}{*}{$\mathrm{E}_{0}(\mathrm{G} 2)$} & -139.55421 & & & -499.55382 & & & -2612.39042 & & \\
\hline & $\mathrm{CD}_{3} \mathrm{~F}\left(\mathrm{C}_{\mathrm{s}}\right)$ & & & $\mathrm{CD}_{3} \mathrm{Cl}\left(\mathrm{C}_{\mathrm{s}}\right)$ & & & $\mathrm{CD}_{3} \mathrm{Br}\left(\mathrm{C}_{\mathrm{s}}\right)$ & & \\
\hline A & 78.627 & & & 78.984 & & & 78.237 & & \\
\hline B & 20.353 & & & 10.883 & & & 7.666 & & \\
\hline $\mathrm{C}$ & 20.353 & & & 10.883 & & & 7.666 & & \\
\hline$v_{1}$ & 897 & 878 & (903) & 667 & 709 & $(701)$ & 537 & 555 & $(577)$ \\
\hline$v_{2}$ & 897 & 878 & (903) & 762 & 775 & $(768)$ & 702 & 699 & $(713)$ \\
\hline$v_{3}$ & 980 & 961 & (991) & 762 & 775 & $(768)$ & 702 & 699 & $(713)$ \\
\hline$v_{4}$ & 1072 & 1064 & $(1072)$ & 1037 & 1057 & (1029) & 999 & 991 & $(992)$ \\
\hline$v_{5}$ & 1072 & 1064 & $(1072)$ & 1053 & 1063 & $(1060)$ & 1052 & 1046 & $(1056)$ \\
\hline$v_{6}$ & 1163 & 1145 & (1136) & 1053 & 1063 & $(1060)$ & 1052 & 1046 & $(1056)$ \\
\hline$v_{7}$ & 2066 & 2085 & (2110) & 2086 & 2145 & $(2160)$ & 2093 & 2115 & $(2160)$ \\
\hline$v_{8}$ & 2198 & 2234 & $(2258)$ & 2237 & 2305 & $(2283)$ & 2253 & 2283 & (2297) \\
\hline$v_{9}$ & 2198 & 2234 & (2258) & 2237 & 2305 & $(2283)$ & 2253 & 2283 & (2297) \\
\hline \multirow[t]{2}{*}{$\mathrm{E}_{0}(\mathrm{G} 2)$} & -139.56353 & & & -499.56307 & & & -2612.39962 & & \\
\hline & $\mathrm{CH}_{2} \mathrm{~F}$ & & & $\mathrm{CH}_{2} \mathrm{Cl}$ & & & $\mathrm{CH}_{2} \mathrm{Br}$ & & \\
\hline$C-X$ & 1.350 & & & 1.701 & & & 1.863 & & \\
\hline C-H & 1.081 & & & 1.078 & & & 1.079 & & \\
\hline $\mathrm{X}-\mathrm{C}-\mathrm{H}$ & 122.16 & & & 122.90 & & & 122.52 & & \\
\hline $\mathrm{H}-\mathrm{C}-\mathrm{H}$ & 114.28 & & & 117.45 & & & 116.74 & & \\
\hline A & 262.823 & & & 275.192 & & & 272.310 & & \\
\hline B & 30.431 & & & 15.849 & & & 11.245 & & \\
\hline $\mathrm{C}$ & 27.626 & & & 15.012 & & & 10.823 & & \\
\hline$v_{1}$ & 768 & 707 & & 440 & 316 & (395) & 450 & 400 & $(368)$ \\
\hline$v_{2}$ & 1133 & 1128 & (1170) & 780 & 840 & (829) & 632 & 666 & $(693)$ \\
\hline$v_{3}$ & 1143 & 1134 & (1223) & 975 & 1006 & & 901 & 912 & $(953)$ \\
\hline$v_{4}$ & 1443 & 1445 & $(1420)$ & 1382 & 1422 & (1391) & 1352 & 1362 & $(1356)$ \\
\hline$v_{5}$ & 2963 & 3014 & $(3044)$ & 2998 & 3106 & $(3055)$ & 2993 & 3048 & \\
\hline$v_{6}$ & 3089 & 3158 & (3184) & 3129 & 3249 & & 3128 & 3192 & \\
\hline \multirow[t]{2}{*}{$\mathrm{E}_{0}(\mathrm{G} 2)$} & -138.89290 & & & -498.89566 & & & -2611.73031 & & \\
\hline & $\mathrm{CD}_{2} \mathrm{~F}$ & & & $\mathrm{CD}_{2} \mathrm{Cl}$ & & & $\mathrm{CD}_{2} \mathrm{Br}$ & & \\
\hline A & 133.088 & & & 138.110 & & & 136.945 & & \\
\hline B & 25.982 & & & 13.497 & & & 9.474 & & \\
\hline
\end{tabular}


Table 1 (continued)

\begin{tabular}{|c|c|c|c|c|c|c|c|c|c|}
\hline $\mathrm{C}$ & 22.096 & & & 12.324 & & & 8.889 & & \\
\hline$v_{1}$ & 604 & 556 & & 344 & 247 & (291) & 352 & 313 & $(263)$ \\
\hline$v_{2}$ & 875 & 868 & (976) & 731 & 757 & & 595 & 626 & $(657)$ \\
\hline$v_{3}$ & 991 & 988 & (1011) & 739 & 792 & (791) & 669 & 679 & (708) \\
\hline$v_{4}$ & 1184 & 1183 & (1191) & 1031 & 1067 & (1045) & 1003 & 1014 & (1016) \\
\hline$v_{5}$ & 2137 & 2173 & (2176) & 2161 & 2240 & & 2157 & 2197 & \\
\hline$v_{6}$ & 2310 & 2364 & & 2339 & 2430 & & 2338 & 2386 & \\
\hline $\mathrm{E}_{0}(\mathrm{G} 2)$ & -138.89846 & & & -498.90104 & & & -2611.73564 & & \\
\hline
\end{tabular}

a) G2 molecular parameters: geometrical structure optimized at the MP2(full)/6-31G(d) level, (bond lengths in $\AA$, valence and dihedral angles in degrees), rotational constants, $\mathrm{ABC}$ in $\mathrm{GHz}$, the total G2-energies in a.u. at $0 \mathrm{~K}$ (ZPE included). The vibrational frequencies $v_{\mathrm{i}}\left(\mathrm{cm}^{-1}\right)$ obtained at the SCF/6-31G(d) level and scaled by 0.8929 (first column), derived in MP2/6-31G(d) calc. (second column) were scaled by 0.935 , 0.950 and 0.935 for fluorine, chlorine and bromine containing reactants/products, respectively. The experimental frequencies in parenthesis

recombination and unimolecular dissociation, while the second is related to an energy barrier. In the first elementary step, a chlorine atom approaching a $\mathrm{CH}_{3} \mathrm{X}$ molecule is oriented in such a manner that enables the formation of a loose molecular complex, MC1X with the long and almost equal contact distances, $\mathrm{Cl} \ldots \mathrm{X}, \mathrm{Cl} \ldots \mathrm{H}_{2}$ and $\mathrm{Cl} \ldots \mathrm{H}_{3}$. The pre-reaction adduct, $\mathrm{MC} 1 \mathrm{Br}$ is the lowest energy structure in the $\mathrm{CH}_{3} \mathrm{Br}+\mathrm{Cl}$ reaction system. The next elementary step leads, via TS1X to the molecular complex MC2X, which dissociates to the final channel products, $\mathrm{CH}_{2} \mathrm{X}+\mathrm{HCl}$. The heights of the energy barrier for the second step calculated for $\mathrm{CH}_{3} \mathrm{Cl}+\mathrm{Cl}$ and $\mathrm{CH}_{3} \mathrm{Br}+\mathrm{Cl}$ are slightly lower than that for $\mathrm{CH}_{3} \mathrm{~F}+\mathrm{Cl}$. This implies either high values of the rate constants or their weak dependence on temperature.

The substitution of a hydrogen atom by deuterium changes physical properties of the molecule. The most distinct differences occur in the $\mathrm{C}-\mathrm{H}$ and $\mathrm{C}-\mathrm{D}$ stretching modes. This results in a decrease of the zero-point vibrational energy (ZPE) of the deuterated reactant compared with the unsubstituted one. The profiles of the potential energy surface for the reactions of the entirely deuterated reactants, $\mathrm{CD}_{3} \mathrm{X}$ with $\mathrm{Cl}$ atom are presented in Fig. 2b. The reactions of deuterated reactants, $\mathrm{CD}_{3} \mathrm{X}+\mathrm{Cl}$ are by $5 \mathrm{~kJ} \mathrm{~mol}^{-1}$ less exothermic compared with those of $\mathrm{CH}_{3} \mathrm{X}+\mathrm{Cl}$. On the other hand, the changes in the relative energy of the pre-reaction adducts related to the $\mathrm{D}$ substitution are only small, around $0.5 \mathrm{~kJ} \mathrm{~mol}^{-1}$. The considerably higher differences appear in the energy of the deuterated $(\mathrm{DMC} 2 \mathrm{X})$ and non-deuterated $(\mathrm{MC} 2 \mathrm{X})$ post-reaction adducts. A decrease of ZPE of the deuterated reactant compared with the unsubstituted one is obviously reflected in the relative energy of the transition states. Consequently, the Dabstraction reaction is thus related to an energy barrier distinctly higher compared with the analogous $\mathrm{H}$-abstraction.

Rate constant calculations

A method for the rate constant calculation for a bimolecular reaction which proceeds through the formation of two weakly bound intermediate complexes (MC1X and $\mathrm{MC} 2 \mathrm{X}$ ) has been successfully applied to describe the kinetics of the H-abstraction from methanol [57-59]. The general equation, which takes into account the rotational energy, is derived from RRKM theory. Accordingly to this formalism, the rate coefficient $k$ for the three-step reaction mechanism, such as for reaction (5) with formation of the pre-reaction (MC1X) and post-reaction (MC2X) adducts, can be expressed as:

$$
\begin{aligned}
k & =\frac{z}{h Q_{R X} Q_{C l}} \int_{V_{T S 1 X}}^{\infty} \sum_{J} W_{M C 1 X}(E, J) \\
& \times \frac{W_{T S 1 X}(E, J)}{W_{M C 1 X}(E, J)+W_{T S 1 X}(E, J)} \\
& \times \frac{W_{M C 2 X}(E, J)}{W_{M C 2 X}(E, J)+W_{T S 1 X}(E, J)} \times \exp (-E / R T) d E
\end{aligned}
$$

where $Q_{R X}$ and $Q_{C l}$ are the partition functions of $\mathrm{CH}_{3} \mathrm{X}$ and atomic chlorine, respectively, with the center of mass partition function factored out of the product $Q_{R X} Q_{C l}$ and included in $z$ together with the partition functions of those inactive degrees of freedom which are not considered by the sums of the states under the integral. $V_{T S I X}$ is the height of the energy barrier toward the reactants $\mathrm{CH}_{3} \mathrm{X}+\mathrm{Cl}$ whereas $W_{T S 1 X}(E, J)$, $W_{M C 1 X}(E, J)$, and $W_{M C 2 X}(E, J)$ denote the sum of the states at energy less than or equal to $E$ and with angular momentum $J$ for the transition state TS1X and the activated complexes for the unimolecular dissociations of MC1X and MC2X, respectively. All computational effort is then related to calculating the sum of the states, $W(E, J)$. This calculation depends on the level at which the conservation of angular momentum is considered and is discussed in detail in refs. [57-59].

Equation (6) can be directly used in the description of kinetics of the reactions $\mathrm{CH}_{3} \mathrm{Cl}+\mathrm{Cl}$ and $\mathrm{CH}_{3} \mathrm{Br}+\mathrm{Cl}$. In the case of the two-step mechanism such as for reaction $\mathrm{CH}_{3} \mathrm{~F}+$ $\mathrm{Cl}$ one should replace $W_{M C I X}(E, J)$ by $W_{T S I X}(E, J)$ and omit 
Table 2 Molecular properties of the structures taking part in the mechanism of the $\mathrm{H} / \mathrm{D}$-abstraction reactions $\mathrm{CH}_{3} \mathrm{X} / \mathrm{CD}_{3} \mathrm{X}+\mathrm{C} 1(\mathrm{X}=\mathrm{F}, \mathrm{C} 1$ and $\mathrm{Br})$ calculated at the G2 level ${ }^{\text {a) }}$

\begin{tabular}{|c|c|c|c|c|c|c|c|c|}
\hline & $\mathrm{TS} 1 \mathrm{~F}$ & $\mathrm{MC} 2 \mathrm{~F}$ & $\mathrm{MC} 1 \mathrm{Cl}$ & $\mathrm{TS} 1 \mathrm{Cl}$ & $\mathrm{MC} 2 \mathrm{Cl}$ & $\mathrm{MC} 1 \mathrm{Br}$ & $\mathrm{TS} 1 \mathrm{Br}$ & $\mathrm{MC} 2 \mathrm{Br}$ \\
\hline $\mathrm{CX}$ & 1.345 & 1.345 & 1.779 & 1.713 & 1.699 & 1.950 & 1.875 & 1.868 \\
\hline $\mathrm{CH}_{1}$ & 1.398 & 2.416 & 1.088 & 1.383 & 2.384 & 1.087 & 1.399 & 3.248 \\
\hline $\mathrm{CH}_{2}$ & 1.088 & 1.082 & 1.088 & 1.087 & 1.080 & 1.086 & 1.086 & 1.079 \\
\hline $\mathrm{CH}_{3}$ & 1.088 & 1.082 & 1.088 & 1.087 & 1.080 & 1.086 & 1.086 & 1.079 \\
\hline $\mathrm{ClH}_{1}$ & 1.454 & 1.286 & & 1.460 & 1.286 & 3.432 & 1.448 & 1.284 \\
\hline $\mathrm{ClX}$ & & & 3.171 & & & 2.941 & & \\
\hline $\mathrm{H}_{1} \mathrm{CX}$ & 107.04 & 107.96 & 110.26 & 108.34 & 101.13 & 107.35 & 106.774 & 54.89 \\
\hline $\mathrm{H}_{1} \mathrm{CH}_{2}$ & 102.03 & 96.79 & 110.13 & 101.01 & 95.39 & 111.54 & 101.98 & 113.27 \\
\hline $\mathrm{H}_{1} \mathrm{CH}_{3}$ & 102.03 & 96.79 & 108.76 & 101.01 & 95.39 & 111.40 & 101.98 & 113.27 \\
\hline $\mathrm{CH}_{1} \mathrm{Cl}$ & 178.94 & 169.72 & & 175.84 & 173.38 & & 175.15 & 141.30 \\
\hline $\mathrm{CIXC}$ & & & 92.42 & & & 89.73 & & \\
\hline $\mathrm{ClH}_{1} \mathrm{CH}_{2}$ & 118.78 & 61.69 & & 59.99 & 61.23 & & 60.74 & 73.04 \\
\hline $\mathrm{ClH}_{1} \mathrm{CH}_{3}$ & -118.78 & 61.69 & & -59.99 & -61.23 & & -60.74 & -73.04 \\
\hline $\mathrm{ClH}_{1} \mathrm{CX}$ & 0.00 & 180.00 & & 180.00 & 180.00 & & 180.00 & 180.00 \\
\hline $\mathrm{ClXCH}_{1}$ & & & 180.00 & & & 180.00 & & \\
\hline $\mathrm{ClXCH}_{2}$ & & & 60.34 & & & 59.54 & & \\
\hline $\mathrm{ClXCH}_{3}$ & & & -60.34 & & & -59.54 & & \\
\hline A & 34.324 & 35.589 & 14.038 & 23.816 & 19.582 & 9.638 & 19.827 & 10.832 \\
\hline B & 2.877 & 1.785 & 2.283 & 1.946 & 1.417 & 2.228 & 1.350 & 1.261 \\
\hline $\mathrm{C}$ & 2.705 & 1.721 & 1.989 & 1.822 & 1.334 & 1.831 & 1.275 & 1.139 \\
\hline$v_{1}$ & $1269 \mathrm{i}$ & 35 & 29 & $1379 \mathrm{i}$ & 31 & 58 & $1297 \mathrm{i}$ & 23 \\
\hline$v_{2}$ & 111 & 83 & 46 & 107 & 86 & 70 & 84 & 37 \\
\hline$v_{3}$ & 350 & 117 & 68 & 368 & 121 & 93 & 362 & 77 \\
\hline$v_{4}$ & 474 & 255 & 741 & 435 & 247 & 585 & 416 & 291 \\
\hline$v_{5}$ & 923 & 297 & 1034 & 833 & 296 & 943 & 673 & 321 \\
\hline$v_{6}$ & 982 & 785 & 1034 & 924 & 592 & 946 & 892 & 407 \\
\hline$v_{7}$ & 1127 & 1137 & 1394 & 960 & 842 & 1306 & 898 & 661 \\
\hline$v_{8}$ & 1156 & 1139 & 1466 & 1072 & 1013 & 1435 & 1016 & 911 \\
\hline$v_{9}$ & 1194 & 1445 & 1467 & 1159 & 1422 & 1437 & 1096 & 1358 \\
\hline$v_{10}$ & 1441 & 2764 & 2996 & 1419 & 2808 & 2957 & 1365 & 2797 \\
\hline$v_{11}$ & 2964 & 3007 & 3104 & 3036 & 3088 & 3074 & 2994 & 3050 \\
\hline$v_{12}$ & 3088 & 3151 & 3105 & 3152 & 3226 & 3080 & 3114 & 3197 \\
\hline \multirow[t]{2}{*}{$\mathrm{E}_{0}(\mathrm{G} 2)^{\mathrm{b})}$} & 9.891 & -9.841 & -9.481 & 8.121 & -16.920 & -18.422 & 8.343 & -13.623 \\
\hline & DTS1F & $\mathrm{DMC} 2 \mathrm{~F}$ & $\mathrm{DMC} 1 \mathrm{Cl}$ & DTS1Cl & $\mathrm{DMC} 2 \mathrm{Cl}$ & $\mathrm{DMC} 1 \mathrm{Br}$ & DTS1Br & $\mathrm{DMC} 2 \mathrm{Br}$ \\
\hline A & 25.923 & 26.955 & 11.552 & 18.282 & 15.505 & 7.817 & 15.318 & 8.932 \\
\hline B & 2.795 & 1.737 & 2.165 & 1.926 & 1.397 & 2.164 & 1.337 & 1.235 \\
\hline $\mathrm{C}$ & 2.614 & 1.671 & 1.867 & 1.784 & 1.305 & 1.732 & 1.250 & 1.102 \\
\hline$v_{1}$ & $948 \mathrm{i}$ & 34 & 21 & $1029 \mathrm{i}$ & 30 & 42 & $975 i$ & 16 \\
\hline$v_{2}$ & 107 & 77 & 42 & 104 & 80 & 65 & 82 & 34 \\
\hline$v_{3}$ & 253 & 85 & 67 & 267 & 87 & 93 & 263 & 77 \\
\hline$v_{4}$ & 417 & 184 & 704 & 386 & 176 & 550 & 365 & 207 \\
\hline$v_{5}$ & 683 & 213 & 777 & 687 & 211 & 701 & 614 & 229 \\
\hline$v_{6}$ & 716 & 617 & 777 & 716 & 461 & 704 & 666 & 319 \\
\hline$v_{7}$ & 876 & 870 & 1055 & 767 & 761 & 988 & 678 & 621 \\
\hline$v_{8}$ & 916 & 989 & 1061 & 777 & 792 & 1040 & 719 & 678 \\
\hline$v_{9}$ & 991 & 1192 & 1062 & 901 & 1068 & 1043 & 854 & 1009 \\
\hline$v_{10}$ & 1187 & 1983 & 2144 & 1063 & 2014 & 2113 & 1014 & 2006 \\
\hline$v_{11}$ & 2142 & 2169 & 2305 & 2195 & 2228 & 2284 & 2163 & 2198 \\
\hline
\end{tabular}


Table 2 (continued)

\begin{tabular}{lllllllll}
\hline$v_{12}$ & 2306 & 2357 & 2306 & 2350 & 2411 & 2289 & 2322 & 2391 \\
$\mathrm{E}_{0}(\mathrm{G} 2)^{\mathrm{b})}$ & 15.125 & -5.979 & -10.088 & 12.949 & -13.280 & -18.656 & 13.523 & -9.489 \\
\hline
\end{tabular}

${ }^{\text {a) }} \mathrm{G} 2$ molecular parameters: geometrical structure optimized at the MP2(full)/6-31G(d) level, (bond lengths in $\AA$, valence and dihedral angles in degrees), rotational constants, $\mathrm{ABC}$ in $\mathrm{GHz}$, the vibrational frequencies $v_{\mathrm{i}}\left(\mathrm{cm}^{-1}\right)$ obtained at the MP2/6-31G(d) level and scaled by $0.935,0.950$ and 0.935 for the molecular structures taking part in the reaction mechanism of $\mathrm{Cl}$ atom with $\mathrm{CH}_{3} \mathrm{~F} / \mathrm{CD}_{3} \mathrm{~F}, \mathrm{CH}_{3} \mathrm{Cl} / \mathrm{CD}_{3} \mathrm{Cl}$ and $\mathrm{CH}{ }_{3} \mathrm{Br} / \mathrm{CD}_{3} \mathrm{Br}$, respectively

b) The total G2-energies in $\mathrm{kJ} \mathrm{mol}^{-1}$ at $0 \mathrm{~K}$ (ZPE included) calculated toward to the G2-energy of the respective reactants energy

the first fraction under the integral in Eq. 6. Analysis of the results of the direct calculations of Brudnik et al. [49, 56] shows that the dominant contribution to the rate constant is given by the states with energy $E$ not higher than $V_{T S I X}+$ 3RT. In the case of a sizable (compared with RT) energy barrier $V_{T S I X}$, the value of the product of the microcanonical branching fractions at an energy slightly higher than $V_{T S I X}$ becomes close to unity. Therefore, if the adducts are not stabilized by collisions and can rapidly undergo subsequent processes, the TST rate constant $k_{T S T}$ seems to be a very good approximation of the exact rate coefficient, especially at ambient temperatures $[49,56,59]$.

\section{Reaction $\mathrm{CH}_{3} \mathrm{~F}+\mathrm{Cl}$}

The values of the calculated rate constants are given in Table 4 . The height of the energy barrier is clearly the major factor determining the magnitude of the rate constant and its dependence on temperature. As is shown in Fig. 2a, the minimum energy path for $\mathrm{CH}_{3} \mathrm{~F}+\mathrm{Cl}$ reaction system that leads to the formation of $\mathrm{CH}_{2} \mathrm{~F}+\mathrm{HCl}$ is characterized by the relatively small height of the energy barrier of $9.9 \mathrm{~kJ} \mathrm{~mol}^{-1}$. The calculated value of the rate constant for the hydrogen abstraction reaction $\mathrm{CH}_{3} \mathrm{~F}+\mathrm{Cl}$ of $3.3 \times 10^{-13} \mathrm{~cm}^{3}$ molecule $\mathrm{s}^{-1}$ at $298 \mathrm{~K}$ is very close to that of $3.5 \times 10^{-13} \mathrm{~cm}^{3}$ molecule $\mathrm{s}^{-1}$ unamimously recommended by the IUPAC and NASA [12-14] evaluations of the kinetic data. Our calculated value of $k$ $\left(\mathrm{CH}_{3} \mathrm{~F}+\mathrm{Cl}\right)$ at room temperature is very close to the reported results of $2.7 \times 10^{-13}$ derived by Hitsuda et al. [19], 3.2 $\times 10^{-13}$ of Wallington et al. [18], $3.4 \times 10^{-13}$ of Tuazon et al. [17], $3.5 \times 10^{-13}$ of Sarzyński et al. [22], (3.5-3.9) $\times 10^{-13}$ of Marinkovic et al. [21], $3.6 \times 10^{-13}$ of Manning and Kurylo [15], and that of $3.8 \times 10^{-13} \mathrm{~cm}^{3}$ molecule $\mathrm{s}^{-1}$ of Tschuikow-Roux et al. [16] after correction taking into account the current value of the rate constant for the reference reaction $\mathrm{CH}_{4}+\mathrm{Cl}$ [65]. Figure 3 shows a comparison of calculated values of $k\left(\mathrm{CH}_{3} \mathrm{~F}+\mathrm{Cl}\right)$ with the available results of experimental measurements in a wide temperature range. The calculated rate constant $k\left(\mathrm{CH}_{3} \mathrm{~F}+\mathrm{Cl}\right)$ can be expressed in the temperature range $200-3000 \mathrm{~K}$ as:

$$
\begin{aligned}
k\left(\mathrm{CH}_{3} \mathrm{~F}+\mathrm{Cl}\right) & =6.75 \times 10^{-12} \times(\mathrm{T} / 300)^{2.12} \\
& \times \exp (-900 / \mathrm{T}) \quad \mathrm{cm}^{3} \text { molecule }^{-1} \mathrm{~s}^{-1}
\end{aligned}
$$

The calculated values of $k\left(\mathrm{CH}_{3} \mathrm{~F}+\mathrm{Cl}\right)$ are, in the temperature range of 300-400 K, in satisfactory agreement with those estimated using the various experimental techniques. At the higher temperatures, our calculated values of $k\left(\mathrm{CH}_{3} \mathrm{~F}+\mathrm{Cl}\right)$ seem to be overestimated. However, the temperature dependence of the rate constant $k\left(\mathrm{CH}_{3} \mathrm{~F}+\mathrm{Cl}\right)$ derived experimentally shows substantial differences in values of either the preexponential factor or the activation energy. This is reflected in the form of the recommended Arrhenius' expression for $k$ $\left(\mathrm{CH}_{3} \mathrm{~F}+\mathrm{Cl}\right) / \mathrm{cm}^{3}$ molecule ${ }^{-1} \mathrm{~s}^{-1}$ of $4.0 \times 10^{-12} \exp (-730 / \mathrm{T})$ preferred by IUPAC [13] and that of $1.96 \times 10^{-11} \exp (-1200 / \mathrm{T})$ favored by NASA [12]. On the other hand, the results of the kinetic investigations performed recently by Marinkovic et al. [21], in the widest temperature range of 200-700 K suggest a non-Arrhenius behavior of the kinetics of $\mathrm{CH}_{3} \mathrm{~F}+\mathrm{Cl}$, which is described by $k\left(\mathrm{CH}_{3} \mathrm{~F}+\mathrm{Cl}\right) / \mathrm{cm}^{3}$ molecule ${ }^{-1} \mathrm{~s}^{-1}$ in the form of the $1.14 \times 10^{-12} \times(\mathrm{T} / 298)^{2.26} \times \exp (-313 / \mathrm{T})$. Unfortunately, there are no other studies on the kinetics $\mathrm{CH}_{3} \mathrm{~F}+\mathrm{Cl}$ conducted at sufficiently high temperatures, which could confirm this conclusion of Marinkovic et al. [21].

\section{Reaction $\mathrm{CH}_{3} \mathrm{Cl}+\mathrm{Cl}$}

The minimum energy path for the reaction $\mathrm{CH}_{3} \mathrm{Cl}+\mathrm{Cl}$ is also shown in Fig. 2a. The mechanism of the H-abstraction from $\mathrm{CH}_{3} \mathrm{Cl}$ by $\mathrm{Cl}$ atoms is complex and consists of three elementary steps including the formation of the pre- and post-reaction adducts, $\mathrm{MC} 1 \mathrm{Cl}$ and $\mathrm{MC} 2 \mathrm{Cl}$. The energy barrier for reaction $\mathrm{CH}_{3} \mathrm{Cl}+\mathrm{Cl}$ of $8.1 \mathrm{~kJ} \mathrm{~mol}^{-1}$ is $1.8 \mathrm{~kJ} \mathrm{~mol}^{-1}$

Table 3 Comparison of the experimental $\Delta H_{f, 298}^{0}$ (exp.) and theoretical $\Delta H_{f, 298}^{0}$ (calc.) values of the enthalpy of formation of the reactants $\mathrm{CH}_{3} \mathrm{X}$ and products $\mathrm{CH}_{2} \mathrm{X},(\mathrm{X}=\mathrm{F}, \mathrm{Cl}$ and $\mathrm{Br})$ obtained at the $\mathrm{G} 2$ level

\begin{tabular}{lcc}
\hline $\begin{array}{l}\text { Molecular } \\
\text { system }\end{array}$ & $\begin{array}{l}\Delta H_{f, 298}^{0}(\text { calc. }) \\
\left(\mathrm{kJmol}^{-1}\right)\end{array}$ & $\begin{array}{l}\Delta H_{f, 298}^{0}(\text { exp. }) \\
\left(\mathrm{kJmol}^{-1}\right)\end{array}$ \\
\hline $\mathrm{CH}_{3} \mathrm{~F}$ & -237.7 & $-238 \pm 8$ \\
$\mathrm{CH}_{3} \mathrm{Cl}$ & -81.4 & $-81.9 \pm 0.6$ \\
$\mathrm{CH}_{3} \mathrm{Br}$ & -32.0 & $-37.7 \pm 1.5$ \\
$\mathrm{CH}_{2} \mathrm{~F}$ & -28.1 & $-32 \pm 8$ \\
$\mathrm{CH}_{2} \mathrm{Cl}$ & 120.4 & $117.3 \pm 3.1$ \\
$\mathrm{CH}_{2} \mathrm{Br}$ & 174.9 & $169 \pm 4$ \\
\hline
\end{tabular}

a) from ref. 12 
Fig. 2 Schematic profiles of the potential energy surfaces for the reactions: a) $\mathrm{CH}_{3} \mathrm{X}+\mathrm{Cl}$, and b) $\mathrm{CD}_{3} \mathrm{X}+\mathrm{Cl}$ where $\mathrm{X}=\mathrm{F}$, $\mathrm{Cl}$ and $\mathrm{Br}$. The energies are calculated at the $\mathrm{G} 2$ level including zero-point energy corrections
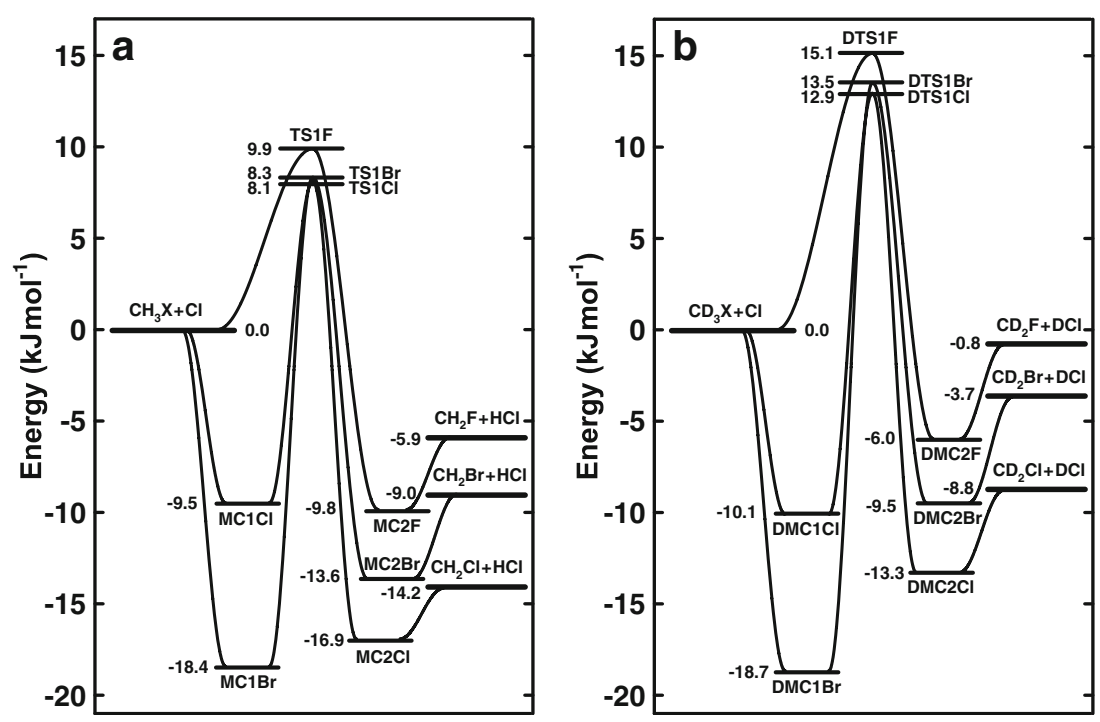

lower than that for $\mathrm{CH}_{3} \mathrm{~F}+\mathrm{Cl}$. The values of the calculated rate constants, $k\left(\mathrm{CH}_{3} \mathrm{Cl}+\mathrm{Cl}\right)$ and $k_{T S T}\left(\mathrm{CH}_{3} \mathrm{Cl}+\mathrm{Cl}\right)$ are collected in Table 5. Our calculated value of $k\left(\mathrm{CH}_{3} \mathrm{Cl}+\mathrm{Cl}\right)$ of $4.5 \times 10^{-13} \mathrm{~cm}^{3}$ molecule $\mathrm{s}^{-1}$ at room temperature is very close to those of $(4.8 \pm 0.5) \times 10^{-13} \mathrm{~cm}^{3}$ molecule ${ }^{-1} \mathrm{~s}^{-1}$ [14] and $(4.9 \pm 0.5) \times 10^{-13} \mathrm{~cm}^{3}$ molecule $\mathrm{s}^{-1}$ [12] recommended by IUPAC and NASA evaluations, respectively. The calculated value of the rate constant at $298 \mathrm{~K}$ can be compared with the reported results of experimental studies [12-14]. Our value of $4.5 \times 10^{-13} \mathrm{~cm}^{3}$ molecule $\mathrm{s}^{-1}$ is in line with the estimate of $(4.4 \pm 0.6) \times 10^{-13}$ obtained by Beichert et al. [27], $(4.7 \pm 0.6) \times 10^{-13}$ of Orlando [28], $(4.8 \pm 0.4) \times 10^{-13}$ of Wallington et al. [26], $(5.1 \pm 1.3) \times 10^{-13}$ of Pritchard et al. [23], $(5.2 \pm 0.4) \times 10^{-13}$ of Sarzyński et al. [32], $(5.2 \pm 0.3) \times 10^{-13}$ of Bryukov et al. [29], and $(5.4 \pm 0.2) \times 10^{-13} \mathrm{~cm}^{3}$ molecule $^{-1} \mathrm{~s}^{-1}$ of Manning and Kurylo [15]. A similar value of $(5.1 \pm 0.7) \times 10^{-13} \mathrm{~cm}^{3}$ molecule $\mathrm{s}^{-1}$ at $298 \mathrm{~K}$ can be derived from the expression describing the temperature dependence of the rate constant found by Tschuikow-Roux et al. [16]. A comparison between the values of the rate constant for the reaction $\mathrm{CH}_{3} \mathrm{Cl}+\mathrm{Cl}$ calculated in this study and available experimental results are shown in Fig. 4. The values of $k$ $\left(\mathrm{CH}_{3} \mathrm{Cl}+\mathrm{Cl}\right)$ can be, in the temperature range of 200-3000 $\mathrm{K}$, expressed as:

$$
\begin{aligned}
k\left(\mathrm{CH}_{3} \mathrm{Cl}+\mathrm{Cl}\right) & =6.97 \times 10^{-12} \times(\mathrm{T} / 300)^{1.73} \\
& \times \exp (-795 / \mathrm{T}) \quad \mathrm{cm}^{3} \text { molecule }^{-1} \mathrm{~s}^{-1}
\end{aligned}
$$

Except for the high temperature range, i.e., above $500 \mathrm{~K}$, the reported values of the rate constant $k\left(\mathrm{CH}_{3} \mathrm{Cl}+\mathrm{Cl}\right)$ estimated by different experimental techniques are very similar from one to another. The discrepancy of the experimental results is only small. The values calculated from Eq. 8 of $k$ $\left(\mathrm{CH}_{3} \mathrm{Cl}+\mathrm{Cl}\right)$ reproduce well the observed trend in experimental results in a wide temperature range. At temperatures above $500 \mathrm{~K}$, the experimental values of $k\left(\mathrm{CH}_{3} \mathrm{Cl}+\mathrm{Cl}\right)$ are limited by the results of Bryukov et al. [29] and Clyne and Walker [25]. The theoretically derived temperature dependence of $k\left(\mathrm{CH}_{3} \mathrm{Cl}+\mathrm{Cl}\right)$ described by Eq. 8 can be considered the best compromise for all experimental points.

Reaction $\mathrm{CH}_{3} \mathrm{Br}+\mathrm{Cl}$

The profile of the potential energy surface for $\mathrm{CH}_{3} \mathrm{Br}+\mathrm{Cl}$ reaction system shows that two molecular complexes, $\mathrm{MC} 1 \mathrm{Br}$ and $\mathrm{MC} 2 \mathrm{Br}$ are formed during reaction as intermediate products. The pre-reaction adduct, $\mathrm{MC} 1 \mathrm{Br}$ is the lowest energy molecular structure in $\mathrm{CH}_{3} \mathrm{Br}+\mathrm{Cl}$ reaction system. The calculated energy barrier corresponding to the relative potential energy of the transition state TS1Br toward the reactants of 8.3 $\mathrm{kJ} \mathrm{mol}^{-1}$, is only slightly higher than that of $8.1 \mathrm{~kJ} \mathrm{~mol}^{-1}$ found for $\mathrm{CH}_{3} \mathrm{Cl}+\mathrm{Cl}$. This implies very similar values of the rate constants for both $\mathrm{CH}_{3} \mathrm{Cl}+\mathrm{Cl}$ and $\mathrm{CH}_{3} \mathrm{Br}+\mathrm{Cl}$ reactions. The results of the rate constant calculations for $\mathrm{CH}_{3} \mathrm{Br}+\mathrm{Cl}$ are given in Table 6. The calculated values of $k\left(\mathrm{CH}_{3} \mathrm{Br}+\mathrm{Cl}\right)$ are compared with experimental ones in Fig. 5. The results of kinetic measurements performed over a wide temperature range and using different experimental techniques are in very good agreement. Especially similar are values of the rate constant derived at room temperature [33-38]. Our calculated value of $k\left(\mathrm{CH}_{3} \mathrm{Br}+\mathrm{Cl}\right)$ of $4.1 \times 10^{-13} \mathrm{~cm}^{3}$ molecule ${ }^{-1} \mathrm{~s}^{-1}$ at $298 \mathrm{~K}$ is close to that of $(4.4 \pm 0.6) \times 10^{-13}$ obtained by Sarzyński et al. [38], $(4.5 \pm 0.4) \times 10^{-13}$ of Gierczak et al. [34], $(4.6 \pm 0.3) \times 10^{-13}$ of Piety et al. [37], and $(4.8 \pm 0.2) \times 10^{-13}$ obtained at $303 \mathrm{~K}$ by Kambanis et al. [36], and value of $(4.4 \pm 0.6) \times 10^{-13} \mathrm{~cm}^{3}$ molecule $\mathrm{s}^{-1}$ derived at $295 \mathrm{~K}$ by Orlando et al. [35]. In addition our value of $k\left(\mathrm{CH}_{3} \mathrm{Br}+\mathrm{Cl}\right)$ is in good agreement with that of $(4.4 \pm 0.2) \times 10^{-13} \mathrm{~cm}^{3}$ molecule $\mathrm{s}^{-1}$ recommended by NASA data evaluation [12] at room temperature. Our $k\left(\mathrm{CH}_{3} \mathrm{Br}+\mathrm{Cl}\right)$-value is also included in the error limits of the estimate of $(5.5 \pm 1.7) \times 10^{-13} \mathrm{~cm}^{3}$ molecule $\mathrm{s}^{-1}$ 


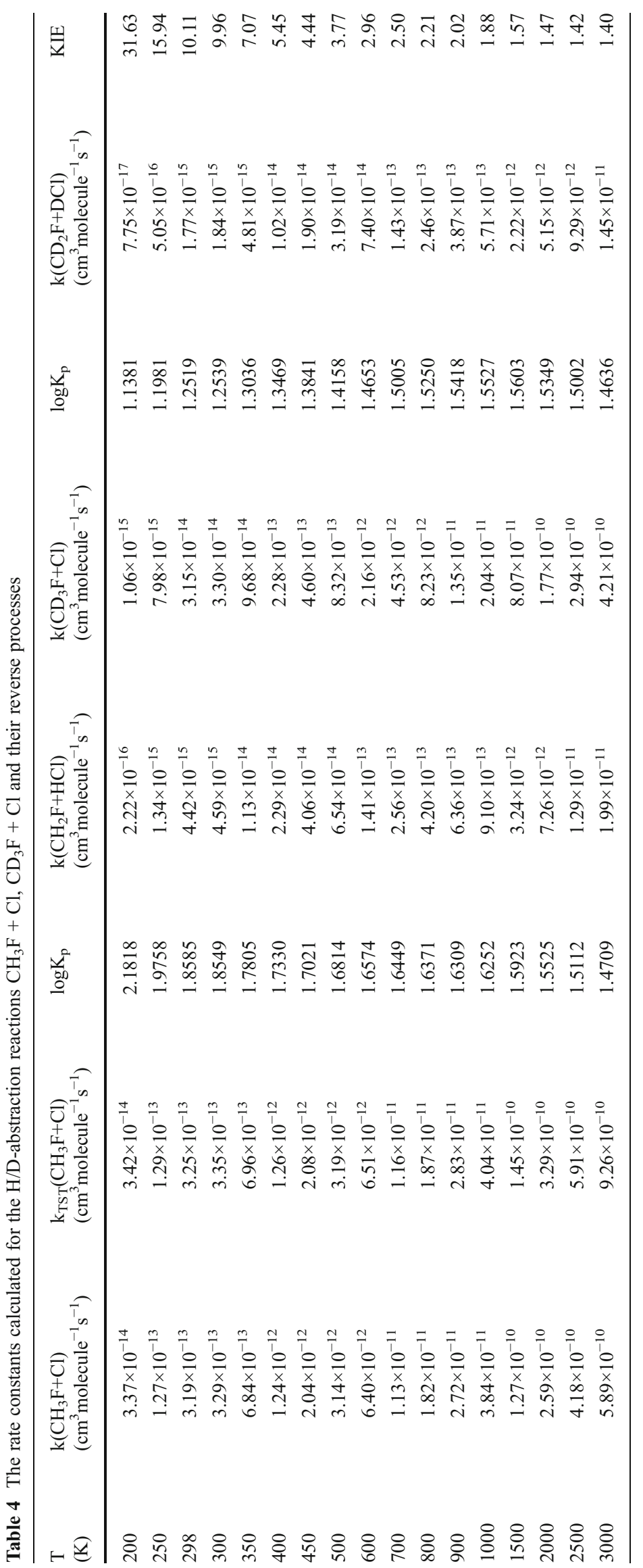




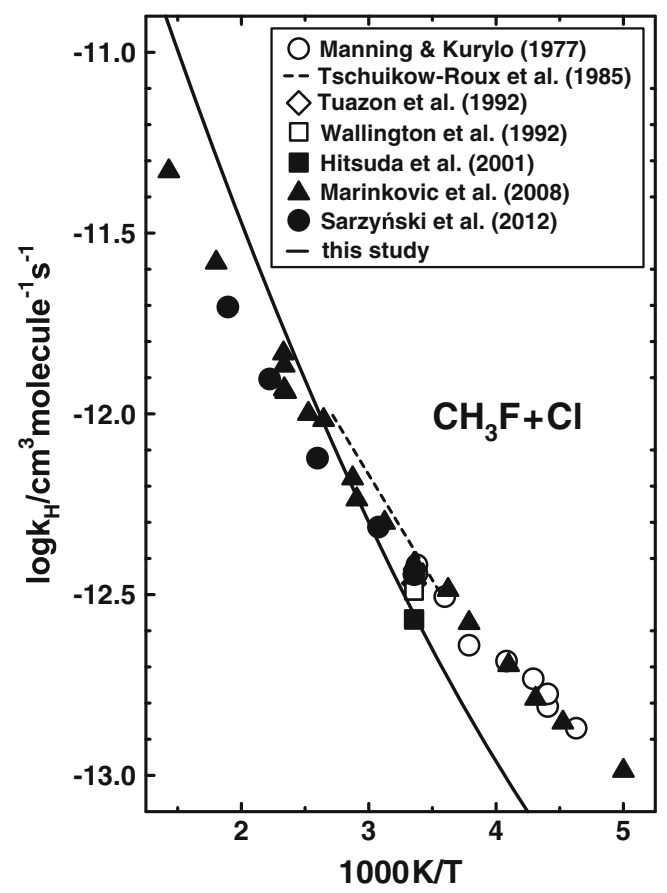

Fig. 3 Arrhenius plot for the $\mathrm{CH}_{3} \mathrm{~F}+\mathrm{Cl}$ reaction comparing the available results of kinetic measurements with obtained theoretically in this study

obtained by Tschuikow-Roux et al. [33]. The temperature dependence of $k\left(\mathrm{CH}_{3} \mathrm{Br}+\mathrm{Cl}\right)$ can be described as:

$$
\begin{aligned}
k\left(\mathrm{CH}_{3} \mathrm{Br}+\mathrm{Cl}\right) & =6.26 \times 10^{-12} \times(\mathrm{T} / 300)^{1.82} \\
& \times \exp (-795 / \mathrm{T}) \quad \mathrm{cm}^{3} \text { molecule }^{-1} \mathrm{~s}^{-1} .
\end{aligned}
$$

Results of the theoretical investigations indicate a nonArrhenius behavior of the reaction kinetics, especially at high temperatures. This is in line with conclusion of Piety et al. [37], however results of the other experimental investigations do not confirm a curvature of the Arrhenius plot. The temperature dependence of the rate constant predicted by Eq. 9 is steeper than that derived by Piety et al. [37] and probably overestimates reaction rate at high temperatures.

\section{Reactions $\mathrm{CH}_{2} \mathrm{~F} / \mathrm{CH}_{2} \mathrm{Cl} / \mathrm{CH}_{2} \mathrm{Br}+\mathrm{HCl}$}

The values of the enthalpy of formation and vibrational levels of the reactants and products calculated at the G2 level are in reasonable agreement with those obtained experimentally. One can expect that the calculated values of the thermodynamic functions and equilibrium constants for the reactions under investigation are realistic. The values of the rate constants for the reverse reactions of $\mathrm{CH}_{2} \mathrm{X}+\mathrm{HCl}$ can be derived via the respective equilibrium constants. The hydrogen chloride, $\mathrm{HCl}$ is considered as a one of the most abundant natural chlorine containing compounds in the atmosphere. A great part of the chlorine released from chlorofluorocarbons is stored in the $\mathrm{HCl}$ reservoir at high altitudes, over $50 \mathrm{~km} \mathrm{[1].}$ The tropospheric concentrations of $\mathrm{HCl}$ reach especially high values either near the surface of remote ocean regions or in the coastal urban areas. Therefore, the kinetics of the reactions of $\mathrm{HCl}$ with such reactive species as the halogenated methyl radicals is of some importance for modeling and kinetic description of the complex processes occurring in the polluted atmosphere. In addition, to the best of our knowledge there is no experimental information on the kinetic investigations of the reactions $\mathrm{CH}_{2} \mathrm{X}+\mathrm{HCl}(\mathrm{X}=\mathrm{F}, \mathrm{Cl}$ and $\mathrm{Br})$ conducted under typical atmospheric conditions. The rate constants, for the reverse reactions derived on the basis of the calculated equilibrium constants can be expressed in the following form:

$$
\begin{aligned}
k\left(\mathrm{CH}_{2} \mathrm{~F}+\mathrm{HCl}\right) & =2.88 \times 10^{-13} \times(\mathrm{T} / 300)^{2.02} \\
& \times \exp (-1255 / \mathrm{T}) \quad \mathrm{cm}^{3} \text { molecule }{ }^{-1} \mathrm{~s}^{-1} \\
k\left(\mathrm{CH}_{2} \mathrm{Cl}+\mathrm{HCl}\right) & =2.42 \times 10^{-13} \times(\mathrm{T} / 300)^{1.57} \\
& \times \exp (-2100 / \mathrm{T}) \quad \mathrm{cm}^{3} \text { molecule } \mathrm{s}^{-1} \mathrm{~s}^{-1}
\end{aligned}
$$

$$
\begin{aligned}
k\left(\mathrm{CH}_{2} \mathrm{Br}+\mathrm{HCl}\right) & =2.21 \times 10^{-13} \times(\mathrm{T} / 300)^{1.69} \\
& \times \exp (-1485 / \mathrm{T}) \quad \mathrm{cm}^{3} \text { molecule }^{-1} \mathrm{~s}^{-1} .
\end{aligned}
$$

The calculated rate constants for the forward processes, $\mathrm{CH}_{3} \mathrm{~F}+\mathrm{Cl}$ and $\mathrm{CH}_{3} \mathrm{Br}+\mathrm{Cl}$ well describe the reaction kinetics in the temperature range of $250-400 \mathrm{~K}$. In the case of $\mathrm{CH}_{3} \mathrm{Cl}+$ $\mathrm{Cl}$, the derived kinetic expression (10) describes very well the reaction kinetics in a whole temperature range. Therefore, the equations (10-12) should reliably describe the values and temperature dependence of $\mathrm{k}\left(\mathrm{CH}_{2} \mathrm{X}+\mathrm{HCl}\right)$ in the temperature ranges given above. The kinetics of the hydrodehalogenation of $\mathrm{CF}_{2} \mathrm{ClBr}$ with hydrogen has been experimentally studied by Yu et al. [66] at the high temperatures of $673-973 \mathrm{~K}$. In their kinetic computational model, the temperature dependence of the rate constant for reaction $\mathrm{CH}_{2} \mathrm{~F}+\mathrm{HCl}$ was described by the Arrhenius equation of $9.56 \times 10^{-13} \times \exp (-1225 / \mathrm{T}) \mathrm{cm}^{3}$ molecule $^{-1} \mathrm{~s}^{-1}$ estimated by referring to the analogous reactions of the halogenated methyl radicals with hydrogen bromide [66]. This leads to values of the rate constant $k\left(\mathrm{CH}_{2} \mathrm{~F}+\mathrm{HCl}\right)$ of $1.66 \times 10^{-13}, 2.06 \times 10^{-13}$ and $2.45 \times 10^{-13} \mathrm{~cm}^{3}$ molecule $^{-1} \mathrm{~s}^{-1}$ at 700,800 and $900 \mathrm{~K}$, respectively. These values are about two times lower than those obtained in this study.

Kinetic isotope effect

The substitution of a hydrogen atom by deuterium changes the physical properties of the molecule. In consequence, the 


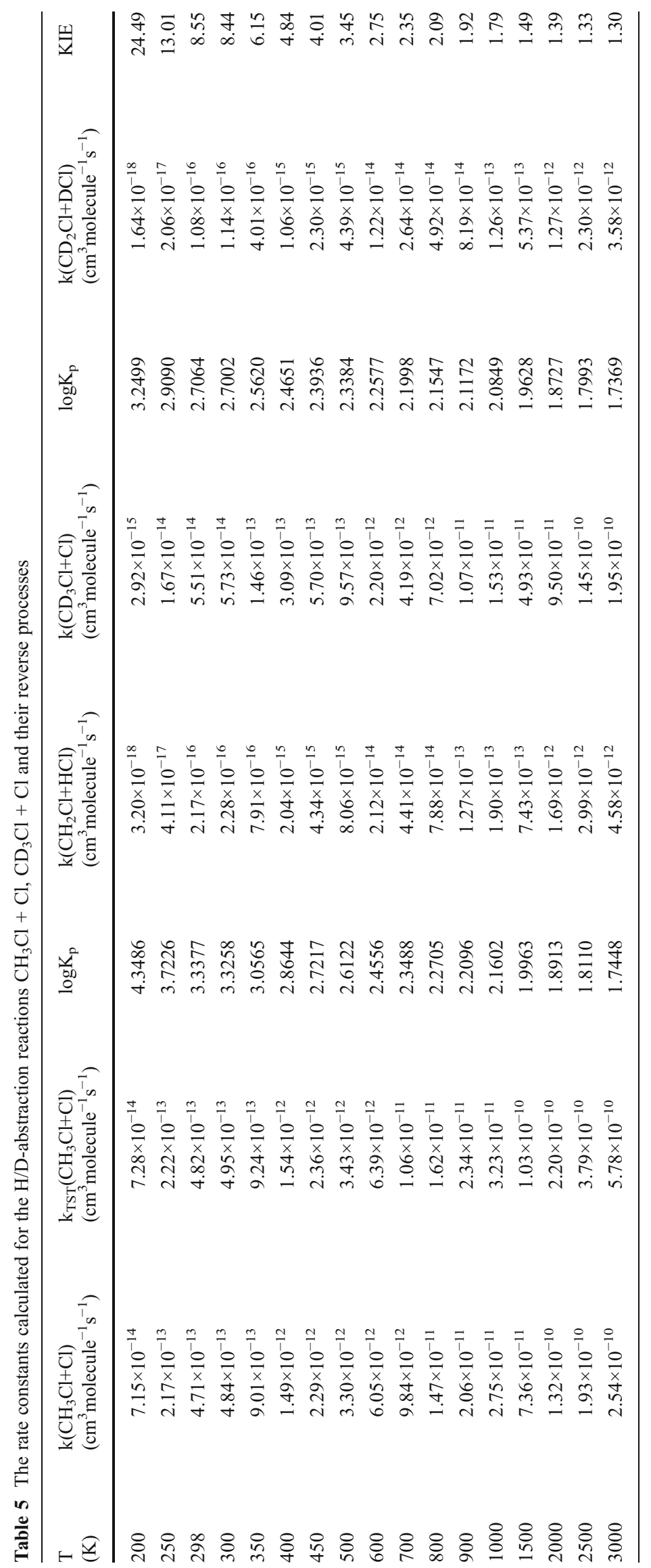




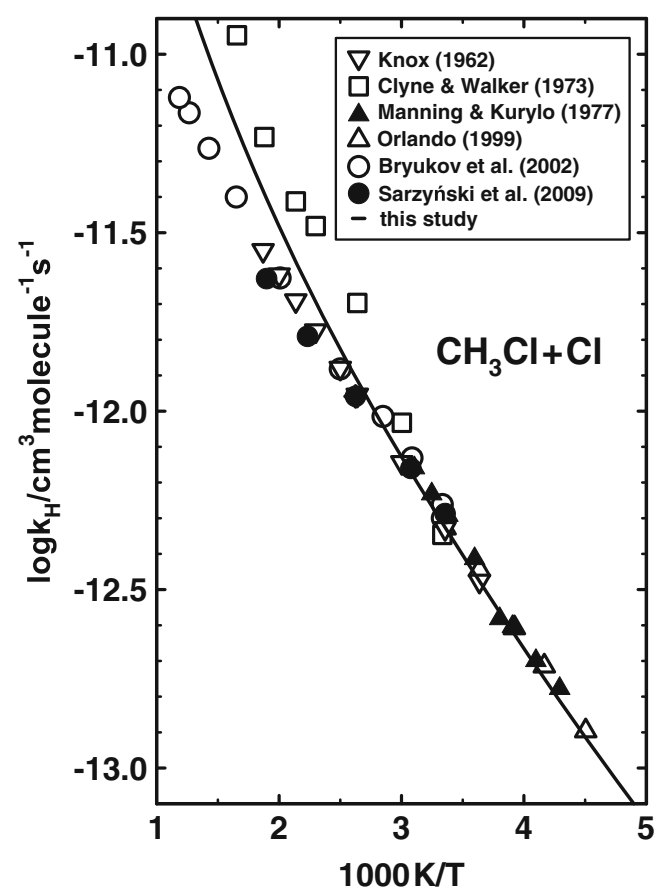

Fig. 4 Arrhenius plot for the $\mathrm{CH}_{3} \mathrm{Cl}+\mathrm{Cl}$ reaction comparing the available results of kinetic measurements with obtained theoretically in this study

deuterated reactants react with a different rate compared to the reaction of non-deuterated molecules. The knowledge of the rate constants, $\mathrm{k}\left(\mathrm{CH}_{3} \mathrm{X}+\mathrm{Cl}\right)$ and $\mathrm{k}\left(\mathrm{CD}_{3} \mathrm{X}+\mathrm{Cl}\right)$ enables a determination of the kinetic isotope effect (KIE), defined by the ratio of $\mathrm{k}\left(\mathrm{CH}_{3} \mathrm{X}+\mathrm{Cl}\right) / \mathrm{k}\left(\mathrm{CD}_{3} \mathrm{X}+\mathrm{Cl}\right)$. Values of $\mathrm{KIE}$ and its dependence on temperature can provide useful information for interpreting the stable isotope composition of the organic compounds in the atmosphere.

The calculated values of the rate constants $\mathrm{k}\left(\mathrm{CD}_{3} \mathrm{X}+\mathrm{Cl}\right)$ for the $\mathrm{D}$-abstraction processes can be analytically written in the form:

$$
\begin{aligned}
k\left(\mathrm{CD}_{3} \mathrm{~F}+\mathrm{Cl}\right) & =9.18 \times 10^{-12} \times(\mathrm{T} / 300)^{1.97} \\
& \times \exp (-1675 / \mathrm{T}) \quad \mathrm{cm}^{3} \text { molecule }^{-1} \mathrm{~s}^{-1}
\end{aligned}
$$

$$
\begin{aligned}
k\left(\mathrm{CD}_{3} \mathrm{Cl}+\mathrm{Cl}\right) & =8.63 \times 10^{-12} \times(\mathrm{T} / 300)^{1.63} \\
& \times \exp (-1490 / \mathrm{T}) \quad \mathrm{cm}^{3} \text { molecule }^{-1} \mathrm{~s}^{-1}
\end{aligned}
$$

$$
\begin{aligned}
k\left(\mathrm{CD}_{3} \mathrm{Br}+\mathrm{Cl}\right) & =8.73 \times 10^{-12} \times(\mathrm{T} / 300)^{1.70} \\
& \times \exp (-1560 / \mathrm{T}) \quad \mathrm{cm}^{3} \text { molecule }^{-1} \mathrm{~s}^{-1} .
\end{aligned}
$$

The profiles of the potential energy surface show that Dabstraction process is related with the energy barrier of $5 \mathrm{~kJ}$ $\mathrm{mol}^{-1}$ higher than the $\mathrm{H}$-abstraction from the corresponding non-deuterated molecule. These differences in the height of the energy barrier are reflected in values of the rate constants. The abstraction of deuterium from $\mathrm{CD}_{3} \mathrm{X}$ by $\mathrm{Cl}$ atom proceeds slower compared with the analogous $\mathrm{H}$-abstraction from $\mathrm{CH}_{3} \mathrm{X}$. The values of the rate constants, $k\left(\mathrm{CD}_{3} \mathrm{X}+\mathrm{Cl}\right)$ are distinctly lower than values of their counterparts, $k\left(\mathrm{CH}_{3} \mathrm{X}\right.$ $+\mathrm{Cl}$ ), especially at low temperatures. The calculated values of $\mathrm{KIE}$ at room temperature are of $10.1,8.6$ and 9.6 for the $\mathrm{CH}_{3} \mathrm{~F} /$ $\mathrm{CD}_{3} \mathrm{~F}, \mathrm{CH}_{3} \mathrm{Cl} / \mathrm{CD}_{3} \mathrm{Cl}$ and $\mathrm{CH}_{3} \mathrm{Br} / \mathrm{CD}_{3} \mathrm{Br}$ reaction systems, respectively. These calculated values of KIE at $298 \mathrm{~K}$ are distinctly higher than those obtained experimentally of 5.1$6.2[21,22], 4.9-5.4$ [30-32] and $6.5 \pm 0.3$ [38] for the reaction systems ordered analogously as above. The significance of the kinetic isotope effect diminishes with rising temperature and the values of KIE at $500 \mathrm{~K}$ are over twice as low as those at room temperature. The values of KIE of 3.8, 3.5 and 3.6 calculated at $500 \mathrm{~K}$ are comparable with those of 3.3, 2.9 and 2.9 derived experimentally in our laboratory $[22,32,38]$ at 527 $\mathrm{K}$ for $\mathrm{CH}_{3} \mathrm{~F} / \mathrm{CD}_{3} \mathrm{~F}, \mathrm{CH}_{3} \mathrm{Cl} / \mathrm{CD}_{3} \mathrm{Cl}$ and $\mathrm{CH}_{3} \mathrm{Br} / \mathrm{CD}_{3} \mathrm{Br}$ reaction systems, respectively. This suggests that values of the calculated rate constants, $k\left(\mathrm{CD}_{3} \mathrm{X}+\mathrm{Cl}\right)$ gain in reliability with a rise in temperature.

There are several possible reasons for the observed disagreement between the theoretical and experimental estimations of KIE. One of them is related to the mechanism of the studied reactions. The stabilization by collisions of the molecular complexes formed during the reactions may need a more detailed approach. The influence of the formed adducts on the reaction kinetics is directly observed in the reactions of atomic chlorine with methyl and ethyl iodides $[67,68]$, which at room and lower temperatures proceed mainly via reversible adduct formation with the distinct pressure dependence of the kinetics of these reactions. At temperatures above $350 \mathrm{~K}$, the rate constants become pressure independent.

It is worth noting that the recent kinetic experimental studies $[22,38]$ proposed a very simple interpretation of the $\mathrm{KIE}$ values for the $\mathrm{CH}_{3} \mathrm{X} / \mathrm{CD}_{3} \mathrm{X}+\mathrm{Cl}$ reaction systems, based on the assumption that the transition states for the investigated $\mathrm{H} / \mathrm{D}$-abstraction reactions are reactant-like structures. In consequence, the vibrational frequencies of the reactant $\left(\mathrm{CH}_{3} \mathrm{X}\right.$ or $\left.\mathrm{CD}_{3} \mathrm{X}\right)$ are very close to those of their counterparts in the respective transition state. The increase in the energy barrier $\Delta E$ for the reaction of the deuterated reactant compared to the non-deuterated one is then given by the change in ZPE during H/D-abstraction. The value of $\Delta E$ is approximately equal to half the difference between the vibrational frequencies of the $\mathrm{C}-\mathrm{H}$ and $\mathrm{C}$ $\mathrm{D}$ stretching modes because one of the $\mathrm{C}-\mathrm{H} / \mathrm{D}$ bonds is broken in the reaction. With the average $\mathrm{C}-\mathrm{H} / \mathrm{D}$ frequencies calculated from those of $2930 \mathrm{~cm}^{-1}$ and $3006(2) \mathrm{cm}^{-1}$ for $\mathrm{CH}_{3} \mathrm{~F}$ [69], $2110 \mathrm{~cm}^{-1}$ and 2258(2) $\mathrm{cm}^{-1}$ for $\mathrm{CD}_{3} \mathrm{~F}$ [69], 


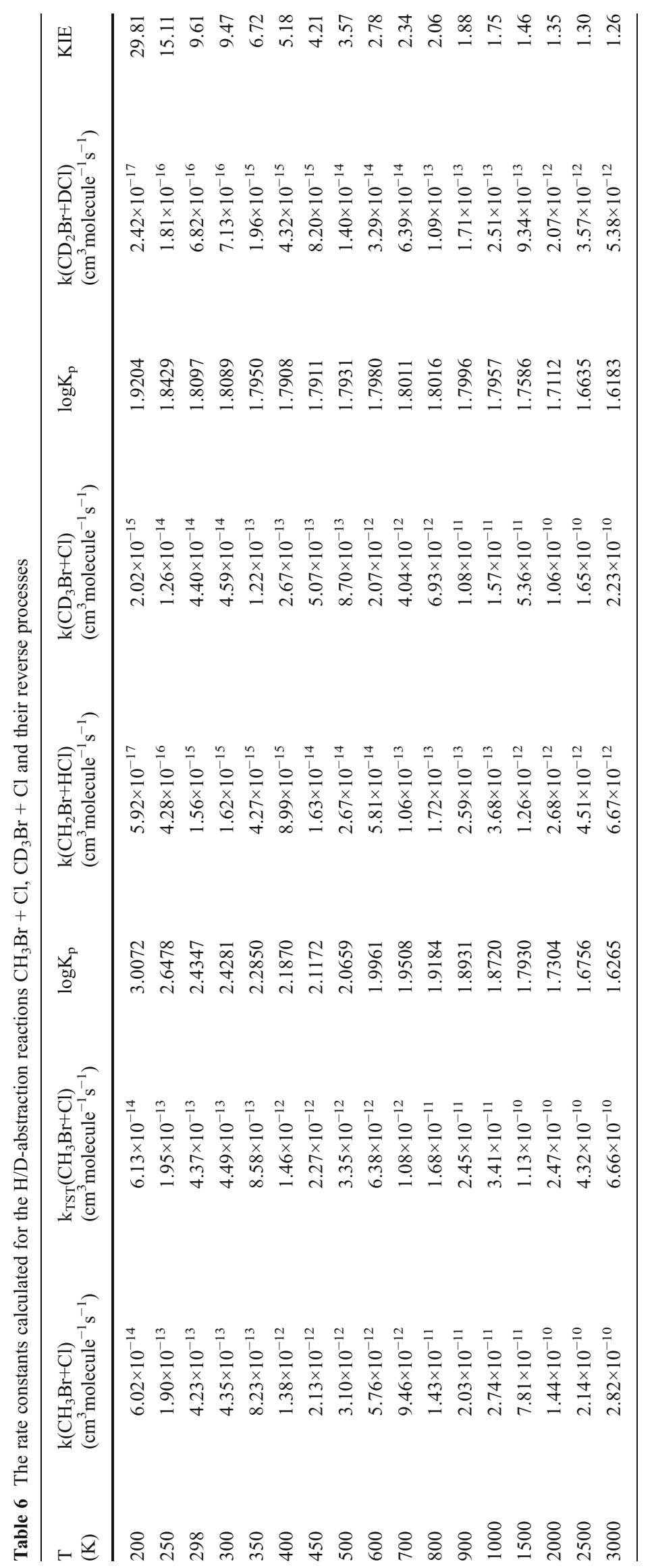




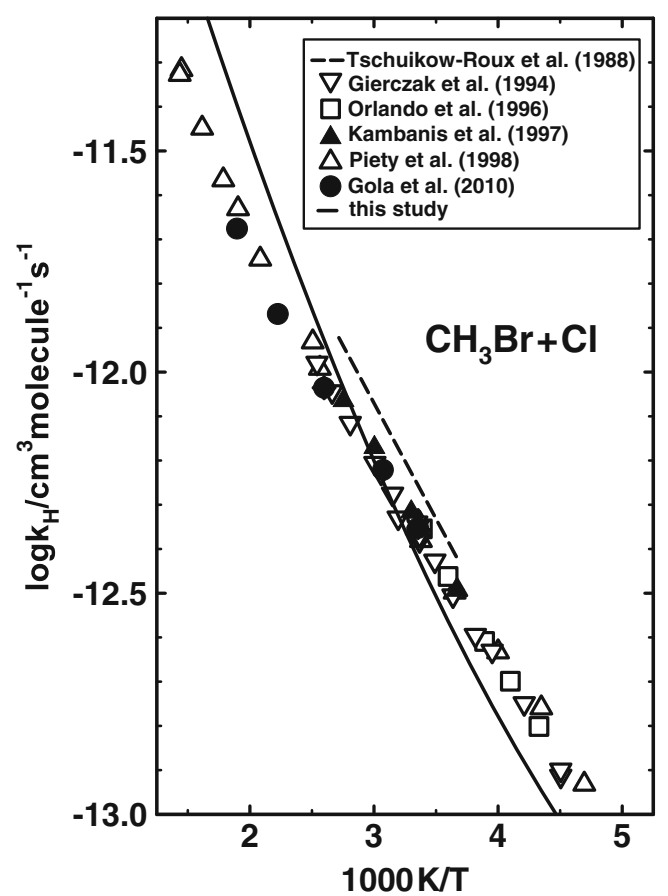

Fig. 5 Arrhenius plot for the $\mathrm{CH}_{3} \mathrm{Br}+\mathrm{Cl}$ reaction comparing the available results of kinetic measurements with obtained theoretically in this study

$2937 \mathrm{~cm}^{-1}$ and 3039(2) $\mathrm{cm}^{-1}$ for $\mathrm{CH}_{3} \mathrm{Cl}$ [69], $2160 \mathrm{~cm}^{-1}$ and 2283(2) $\mathrm{cm}^{-1}$ for $\mathrm{CD}_{3} \mathrm{Cl}[69], 2935$ and 3056(2) $\mathrm{cm}^{-1}$ for $\mathrm{CH}_{3} \mathrm{Br}$ [69], and 2160 and 2297(2) $\mathrm{cm}^{-1}$ for $\mathrm{CD}_{3} \mathrm{Br}$ [69], one can obtain a value for $\Delta E$ of 386,382 and $382 \mathrm{~cm}^{-1}$, for $\mathrm{CH}_{3} \mathrm{~F} / \mathrm{CD}_{3} \mathrm{~F}+\mathrm{Cl}, \mathrm{CH}_{3} \mathrm{Cl} / \mathrm{CD}_{3} \mathrm{Cl}+\mathrm{Cl}$ and $\mathrm{CH}_{3} \mathrm{Br} / \mathrm{CD}_{3} \mathrm{Br}+$ $\mathrm{Cl}$ reaction systems, respectively. Assuming no influence of tunneling correction on the KIE, the value of the KIE can be approximately described by $\exp (\Delta E / R T)$. These values of $\Delta E$ lead to very similar values of KIE, which is confirmed by results of the measurements using the same experimental techniques and methodology. The derived from $\exp (\Delta E / R T)$ values of KIE are of 6.3, 4.2 and 2.8 for the all investigated systems at the 298, 385 and $527 \mathrm{~K}$, respectively. These values are in line with results of measurements of KIE at the same temperatures of $6.2 \pm 0.4,4.2 \pm 0.3$ and $3.3 \pm 0.2$ for $\mathrm{CH}_{3} \mathrm{~F} /$ $\mathrm{CD}_{3} \mathrm{~F}+\mathrm{Cl}$ [22], of $5.4 \pm 0.3,4.2 \pm 0.2$ and $2.9 \pm 0.2$ for $\mathrm{CH}_{3} \mathrm{Cl} /$ $\mathrm{CD}_{3} \mathrm{Cl}+\mathrm{Cl}$ [32] , and $6.5 \pm 0.4,4.8 \pm 0.3$ and $2.9 \pm 0.2$ for $\mathrm{CH}_{3} \mathrm{Br} / \mathrm{CD}_{3} \mathrm{Br}+\mathrm{Cl}$ [38]. In spite of simplicity of the computational procedure the calculated KIE values are in better agreement with results of experiments than those obtained using the advanced theoretical kinetic models. This agreement supports the conclusion that changes in $\mathrm{ZPE}$ during the $\mathrm{CH}_{3} \mathrm{X} / \mathrm{CD}_{3} \mathrm{X}+\mathrm{Cl}$ reactions seem to make a predominant contribution to the KIE. It also suggests that the molecular structure of the transition states for reactions $\mathrm{CH}_{3} \mathrm{X}+\mathrm{Cl}$ should be a more reactant-like structure than those derived by quantum chemistry methods so far.

The derived values of the rate constants, $k\left(\mathrm{CD}_{3} \mathrm{X}+\mathrm{Cl}\right)$ enable also a determination of the rate constants for the backward processes, $\mathrm{CD}_{2} \mathrm{X}+\mathrm{DCl}$ via the calculated equilibrium constants. The obtained values of $k\left(\mathrm{CD}_{2} \mathrm{X}+\mathrm{HCl}\right)$ can be expressed as:

$$
\begin{aligned}
k\left(\mathrm{CD}_{2} \mathrm{~F}+\mathrm{DCl}\right)= & 1.57 \times 10^{-13} \times(\mathrm{T} / 300)^{2.18} \\
\times & \exp (-1340 / \mathrm{T}) \quad \mathrm{cm}^{3} \text { molecule }^{-1} \mathrm{~s}^{-1} \\
k\left(\mathrm{CD}_{2} \mathrm{Cl}+\mathrm{DCl}\right) & =1.11 \times 10^{-13} \times(\mathrm{T} / 300)^{1.82} \\
& \times \exp (-2070 / \mathrm{T}) \quad \mathrm{cm}^{3} \text { molecule }{ }^{-1} \mathrm{~s}^{-1} \\
& \\
k\left(\mathrm{CD}_{2} \mathrm{Br}+\mathrm{DCl}\right) & =1.17 \times 10^{-12} \times(\mathrm{T} / 300)^{1.90} \\
& \times \exp (-1535 / \mathrm{T}) \quad \mathrm{cm}^{3} \text { molecule }
\end{aligned}
$$

There is no experimental data on kinetics of this class of reactions. One can expect that the most credible values of $k$ $\left(\mathrm{CD}_{2} \mathrm{X}+\mathrm{DCl}\right)$ are those describing the reaction kinetics at high temperatures.

\section{Conclusions}

The main aim of the present study is related to a theoretical analysis of the kinetics of the hydrogen abstraction from monohalogenated methanes by chlorine atoms. Theoretical investigations based on ab initio calculations of the $\mathrm{CH}_{3} \mathrm{X}+$ $\mathrm{Cl}(\mathrm{X}=\mathrm{F}, \mathrm{Cl}$ and $\mathrm{Br})$ reaction systems at the $\mathrm{G} 2$ level were performed to gain insight into the reaction mechanism. The results of the calculations also allow an estimation of the reaction energetics and the molecular properties of the structures taking part in the reaction mechanism.

The calculated values of the enthalpy of formation of the reactants and products are in very good agreement with the reported values estimated experimentally. All the reactions studied are exothermic processes, with the calculated values of the reaction enthalpy at $298 \mathrm{~K}$ of $-5.9,-9.0$ and $-14.2 \mathrm{~kJ}$ $\mathrm{mol}^{-1}$ for $\mathrm{CH}_{3} \mathrm{~F}+\mathrm{Cl}, \mathrm{CH}_{3} \mathrm{Br}+\mathrm{Cl}$ and $\mathrm{CH}_{3} \mathrm{Cl}+\mathrm{Cl}$, respectively.

The calculated profiles of the potential energy surface of the reaction systems show that the mechanism of the reactions studied is complex and the $\mathrm{H}$-abstraction proceeds via the formation of intermediate complexes. The multi-step reaction mechanism consists of two - in the case of $\mathrm{CH}_{3} \mathrm{~F}+\mathrm{Cl}$ - and of three for $\mathrm{CH}_{3} \mathrm{Cl}+\mathrm{Cl}$ and $\mathrm{CH}_{3} \mathrm{Br}+\mathrm{Cl}$ elementary steps. The heights of the energy barrier related to the $\mathrm{H}$-abstraction are of 8-10 $\mathrm{kJ} \mathrm{mol}^{-1}$, the lowest value corresponds to $\mathrm{CH}_{3} \mathrm{Cl}+\mathrm{Cl}$ and the highest one to $\mathrm{CH}_{3} \mathrm{~F}+\mathrm{Cl}$. These low energy barriers result in the high values of the rate constants, of $10^{-13}$ 
$\mathrm{cm}^{3}$ molecule $\mathrm{s}^{-1}$ at room temperature. The rate constants were calculated using the theoretical method based on the RRKM theory and the simplified version of the statistical adiabatic channel model [57]. However, the values of the rate constant calculated at the low temperatures (i.e., below 1000 $\mathrm{K}$ ) using the conventional transition state theory are very close to those derived in the exact calculations.

The calculated values of the rate constants well describe the kinetics of $\mathrm{CH}_{3} \mathrm{X}+\mathrm{Cl}$ reactions systems. An especially good agreement between the calculated and reported values of the rate constant has been reached for the reaction $\mathrm{CH}_{3} \mathrm{Cl}+\mathrm{Cl}$. The calculated values of the rate constant for this reaction indeed form the trend line in the experimentally estimated results. The derived kinetic expression describes very well the kinetics of $\mathrm{CH}_{3} \mathrm{Cl}+\mathrm{Cl}$ in the whole range of the experimental measurements of 250-1000 K, with an accuracy at least no worse than the one given by various kinetic data evaluations. In the temperature range of $250-400 \mathrm{~K}$, the kinetic parameters derived theoretically also allow a quantitative description of the reaction kinetics of $\mathrm{CH}_{3} \mathrm{~F}+\mathrm{Cl}$ and $\mathrm{CH}_{3} \mathrm{Br}+\mathrm{Cl}$. At the higher temperatures, the agreement between the calculated and experimental values of the rate constants for these reactions deteriorates because the calculated values of $\mathrm{k}\left(\mathrm{CH}_{3} \mathrm{~F}+\mathrm{Cl}\right)$ and $\mathrm{k}\left(\mathrm{CH}_{3} \mathrm{Br}+\mathrm{Cl}\right)$ slightly exceed the experimental findings. This may be an effect of the treatment of the lowest degrees of freedom of TS1F and TS1Br as the harmonic vibrations.

The substitution of a hydrogen atom by deuterium changes the physical properties of the reactant molecules, which may essentially have an influence on the kinetics of the reactions studied. The results of the reaction path calculations show that the $\mathrm{D}$-abstraction is related with the energy barrier of $5 \mathrm{~kJ} \mathrm{~mol}^{-1}$ higher than the $\mathrm{H}$-abstraction from the corresponding non-deuterated reactant molecule. The calculated values of the rate constants $k\left(\mathrm{CD}_{3} \mathrm{X}+\mathrm{Cl}\right)$ are distinctly lower compared with the values of their counterparts, $k\left(\mathrm{CH}_{3} \mathrm{X}+\mathrm{Cl}\right)$, especially at low temperatures. On the other hand, the values derived in this study and the reported values of KIE [21] calculated at the different levels of theory are higher than those estimated experimentally. It may suggest that the stabilization by collisions of the molecular complexes formed during the reaction should be explicitly considered in the description of the reaction kinetics. The formation of the molecular complexes is experimentally observed in the case of reactions of iodomethane and iodoethane with chlorine atoms $[67,68]$. This is probably a reason for the serious discrepancy in the reported values of $\mathrm{KIE}$ for $\mathrm{CH}_{3} \mathrm{I} / \mathrm{CD}_{3} \mathrm{I}+\mathrm{Cl}$ and $\mathrm{C}_{2} \mathrm{H}_{5} \mathrm{I} / \mathrm{C}_{2} \mathrm{D}_{5} \mathrm{I}+\mathrm{Cl}$ reaction systems at temperatures below $350 \mathrm{~K}$. There are also some arguments in support of the conclusion that changes in ZPE during the $\mathrm{CH}_{3} \mathrm{X} / \mathrm{CD}_{3} \mathrm{X}+\mathrm{Cl}$ reactions seem to make a predominant contribution to KIE. If it is assumed that the transition states for the investigated $\mathrm{H} / \mathrm{D}$-abstraction reactions are very reactant-like structures then the increase in the energy barrier for D-abstraction, $\Delta E$ should be approximately equal to half the difference of the vibrational frequencies of the $\mathrm{C}-\mathrm{H}$ and C-D stretching modes because one of the $\mathrm{C}-\mathrm{H} / \mathrm{D}$ bonds is broken in the reaction. The values of KIE for the reactions derived in this simple way as calculated from the expression $\exp (\Delta E / \mathrm{RT})$ are in good agreement with experimental estimates. This may suggest that the molecular structures of the transition states, TS1X obtained in the geometry optimization by quantum chemistry should be more reactant-like structures, which is an incentive to further theoretical studies.

The rate constants, for the reverse reactions $\mathrm{CH}_{2} \mathrm{X}+\mathrm{Cl}$ and $\mathrm{CD}_{2} \mathrm{Cl}+\mathrm{DCl}$ were derived based on the calculated equilibrium constants. There is no experimental information on the kinetics of this class of reactions. Therefore, the derived values of the rate constants, $\mathrm{k}\left(\mathrm{CH}_{2} \mathrm{X}+\mathrm{HCl}\right)$ and $\mathrm{k}$ $\left(\mathrm{CD}_{2} \mathrm{Cl}+\mathrm{DCl}\right)$ are a substantial supplement of the kinetic data necessary for description and modeling of the processes of importance in atmospheric chemistry.

Acknowledgments This research was supported by Wroclaw Medical University under grant No. ST-517. The Wroclaw Center of Networking and Supercomputing is acknowledged for the generous allotment of computer time.

Open Access This article is distributed under the terms of the Creative Commons Attribution License which permits any use, distribution, and reproduction in any medium, provided the original author(s) and the source are credited.

\section{References}

1. Finnlayson-Pitts BJ, Pitts JN Jr (2000) Chemistry of the upper and lower atmosphere. Academic, San Diego

2. Brasseur GP, Orlando JJ, Tyndall GS (1999) Atmospheric chemistry and global change. Oxford Univ Press, Oxford

3. Harper DB (2000) Nat Prod Rep 17:337-348

4. Tsai W-T (2005) Chemosphere 61:1539-1547

5. Molina MJ, Rowland FS (1974) Nature 249:810-812

6. Ravishankara AR, Solomon S, Turnipseed AA, Warren RF (1993) Science 259:194-199

7. Khalil MAK, Rasmussen RA (1999) Atmos Environ 33:13051321

8. Keene WC, Khalil MA, Erikson DJ, McCulloch A, Graedel TE, Lobert JM, Aucott ML, Gong SL, Harper DB, Kleiman G, Midgley P, Moore RM, Seuzaret C, Sturges WT, Benkovitz CM, Koropalov V, Barrie LA, Li YF (1999) J Geophys Res 104:8429-8440

9. Prather MJ, Watson RT (1990) Nature (London) 344:729-734

10. Mellouki A, Talukdar RK, Schmoltner AM, Gierczak T, Mills MJ, Solomon S, Ravishankara AR (1992) Geophys Ress Lett 19:20592062

11. Orlando JJ, Tyndall GS, Wallington TJ (1996) J Phys Chem 100:7026-7033

12. Sander SP, Friendl RR, Golden DM, Kurylo MJ, Moorgat GK, Wine PH, Ravishankara AR, Kolb CE, Molina MJ, Finlayson-Pitts BJ, Huie RE, Orkin VL (2006) NASA panel for data evaluation: chemical kinetics and photochemical data for use in atmospheric studies, evaluation number 15 , national aeronautics and space 
administration, Jet propulsion laboratory. California Institute of Technology, Pasadena

13. Atkinson R, Baulch DL, Cox RA, Crowley JN, Hampson RF, Hynes RG, Jenkin ME, Rossi MJ, Troe J (2006) Atmos Chem Phys 6:3625-4055

14. Atkinson R, Baulch DL, Cox RA, Crowley JN, Hampson RF, Hynes RG, Jenkin ME, Rossi MJ, Troe J, Wallington TJ (2008) Atmos Chem Phys 8:4141-4496

15. Manning RG, Kurylo MJ (1977) J Phys Chem 81:291-296

16. Tschuikow-Roux E, Yano T, Niedzielski J (1985) J Chem Phys 82:65-74

17. Tuazon EC, Atkinson R, Corchnoy SB (1992) Int J Chem Kinet $24: 639-648$

18. Wallington TJ, Ball JC, Nielsen OJ, Bartkiewicz E (1992) J Phys Chem 96:1241-1246

19. Hitsuda K, Takahashi K, Matsumi Y, Wallington TJ (2001) J Phys Chem A 105:5131-5136

20. Murray C, Retail B, Orr-Ewing AJ (2004) Chem Phys 301:239249

21. Marinkovic M, Gruber-Stadler M, Nicovich JM, Soller R, Mülhäuser M, Wine PH, Bache-Andreassen L, Nielsen CJ (2008) J Phys Chem A 112:12416-12429

22. Sarzyński D, Gola AA, Brudnik K, Jodkowski JT (2012) Chem Phys Lett 525-526:32-36

23. Pritchard HO, Pyke JB, Trotman-Dickenson AF (1955) J Am Chem Soc 77:2629-2633

24. Knox JH (1962) Trans Faraday Soc 58:275-283

25. Clyne MAA, Walker RF (1973) J Chem Soc Faraday Trans I 69:1547-1567

26. Wallington TJ, Andino JM, Ball J, Japar SM (1990) J Atm Chem 10:301-313

27. Beichert P, Wingen L, Lee J, Vogt R, Ezell MJ, Ragains M, Neavyn R, Finlayson-Pitts BJ (1995) J Phys Chem 99:1315613162

28. Orlando JJ (1999) Int J Chem Kinet 31:515-524

29. Bryukov MG, Slagle IR, Knyazev VD (2002) J Phys Chem A 106:10532-10542

30. Wallington TJ, Hurley MD (1992) Chem Phys Lett 189:437-442

31. Gola AA, D'Anna B, Feilberg KL, Sellevag SR, BacheAndreassen L, Nielsen CJ (2005) Atmos Chem Phys 5:2395-2402

32. Sarzyński D, Gola AA, Dryś A, Jodkowski JT (2009) Chem Phys Lett 476:138-142

33. Tschuikow-Roux E, Faraji F, Paddison S, Niedzielski J, Miyokawa K (1988) J Chem Phys 92:1488-1495

34. Gierczak T, Goldfarb L, Super D, Ravishankara AR (1994) Int J Chem Kinet 26:719-728

35. Orlando JJ, Tyndall GS, Wallington TJ, Dill M (1996) Int J Chem Kinet 28:433-442

36. Kambanis KG, Lazarou YG, Papagiannakopoulos P (1997) J Phys Chem A 101:8496-8502

37. Piety CA, Soller R, Nicovich JM, McKee ML, Wine PH (1998) Chem Phys 231:155-169

38. Gola AA, Sarzyński D, Dryś A, Jodkowski JT (2010) Chem Phys Lett 486:7-11

39. Senkan SM, Quam D (1992) J Phys Chem 96:10837-10842

40. Rayez MT, Rayez JC, Sawerysyn JP (1994) J Phys Chem 98:11342-11352

41. Rosenman E, McKee ML (1997) J Am Chem Soc 119:9033-9038

42. Knyazev VD (2003) J Phys Chem A 107:11082-11091

43. Li QS, Xu DX, Zhang SW (2004) Chem Phys Lett 384:20-24

44. Chan B, Radom L (2012) J Phys Chem A 116:3745-3752
45. Curtiss LA, Raghavachari K, Trucks GW, Pople JA (1991) J Chem Phys 94:7221-7230

46. Notario R, Castaño O, Abboud JLM (1996) Chem Phys Lett 263:367-370

47. Espinosa-Garcia J (1999) Chem Phys Lett 315:239-247

48. Segovia M, Ventura ON (1997) Chem Phys Lett 277:490-496

49. Brudnik K, Jodkowski JT, Ratajczak E, Venkatraman R, Nowek A, Sullivan RH (2001) Chem Phys Lett 345:435-444

50. Fernández LE, Varetti EL (2003) J Mol Struct (THEOCHEM) 629:175-183

51. Brudnik K, Jodkowski JT, Ratajczak E (2003) J Mol Struct 656:333-339

52. Brudnik K, Jodkowski JT, Ratajczak E (2003) Bull Pol Acad Sci Chem 51:77-91

53. Brudnik K, Jodkowski JT, Nowek A, Leszczynski J (2007) Chem Phys Lett 435:194-200

54. Brudnik K, Wójcik-Pastuszka D, Jodkowski JT, Leszczynski J (2008) J Mol Model 14:1159-1172

55. Brudnik K, Gola AA, Jodkowski JT (2009) J Mol Model 15:10611066

56. Brudnik K, Jodkowski JT, Sarzyński D, Nowek A, Mol J (2011) Model 17:2395-2409

57. Jodkowski JT, Rayez MT, Rayez JC, Bérces T, Dóbé S (1998) J Phys Chem A 102:9219-9229

58. Jodkowski JT, Rayez MT, Rayez JC, Bérces T, Dóbé S (1998) J Phys Chem A 102:9230-9243

59. Jodkowski JT, Rayez MT, Rayez JC, Bérces T, Dóbé S (1999) J Phys Chem A 103:3750-3765

60. Frisch MJ, Trucks GW, Schlegel HB, Scuseria GE, Robb MA, Cheeseman JR, Scalmani G, Barone V, Mennucci B, Petersson GA, Nakatsuji H, Caricato M, Li X, Hratchian HP, Izmaylov AF, Bloino J, Zheng G, Sonnenberg JL, Hada M, Ehara M, Toyota K, Fukuda R, Hasegawa J, Ishida M, Nakajima T, Honda Y, Kitao O, Nakai H, Vreven T, Montgomery JA Jr, Peralta JE, Ogliaro F, Bearpark M, Heyd JJ, Brothers E, Kudin KN, Staroverov VN, Kobayashi R, Normand J, Raghavachari K, Rendell A, Burant JC, Iyengar SS, Tomasi J, Cossi M, Rega N, Millam JM, Klene M, Knox JE, Cross JB, Bakken V, Adamo C, Jaramillo J, Gomperts R, Stratmann RE, Yazyev O, Austin AJ, Cammi R, Pomelli C, Ochterski JW, Martin R, Morokuma K, Zakrzewski VG, Voth GA, Salvador P, Dannenberg JJ, Dapprich S, Daniels AD, Farkas O, Foresman JB, Ortiz JV, Cioslowski J, Fox DJ (2009) Gaussian 09, revision a 02 . Gaussian Inc, Wallingford

61. Johnston HS (1966) Gas-phase reaction rate theory. The Ronald Press Co, New York

62. Laidler KJ (1969) Theories of chemical reaction rates. McGraw-Hill, New York

63. Curtiss LA, McGrath MP, Blaudeau JP, Davis NE, Binning RC, Radon I (1995) J Chem Phys 103:6104-6113

64. Curtiss LA, Raghavachari K, Redfern PC, Pople JA (1997) J Chem Phys 106:1063-1079

65. Pilgrim JS, McIlroy A, Taatjes CA (1997) J Phys Chem A 101:1873-1880

66. Yu H, Kennedy EM, Uddin A, Sullivan SP, Dlugogorski BZ (2005) Environ Sci Technol 39:3020-3028

67. Dookwah-Roberts V, Nicovich JM, Wine PH (2008) J Phys Chem A 112:9535-9543

68. Wada R, Sharma RC, Blitz MA, Seakins PW (2009) Phys Chem Chem Phys 11:10417-10426

69. Shimanouchi T (1972) Tables of molecular vibrational frequencies consolidated, vol I. National Bureau of Standards, NSRDS-NBS, 39 